\title{
The Impact of Corporate Sustainability on Organizational Processes and Performance
}

\section{Citation}

Eccles, Robert G., loannis loannou, and George Serafeim. "The Impact of Corporate Sustainability on Organizational Processes and Performance." Management Science 60, no. 11 (November 2014): 2835-2857.

\section{Published Version}

http://pubsonline.informs.org/doi/abs/10.1287/mnsc.2014.1984

\section{Permanent link}

http://nrs.harvard.edu/urn-3:HUL.InstRepos:15788003

\section{Terms of Use}

This article was downloaded from Harvard University's DASH repository, and is made available under the terms and conditions applicable to Open Access Policy Articles, as set forth at http:// nrs.harvard.edu/urn-3:HUL.InstRepos:dash.current.terms-of-use\#OAP

\section{Share Your Story}

The Harvard community has made this article openly available.

Please share how this access benefits you. Submit a story.

Accessibility 


\title{
The Impact of Corporate Sustainability on Organizational Processes and Performance
}

\author{
Robert G. Eccles, Ioannis Ioannou, and George Serafeim*
}

\begin{abstract}
We investigate the effect of corporate sustainability on organizational processes and performance. Using a matched sample of 180 US companies, we find that corporations that voluntarily adopted sustainability policies by 1993 - termed as High Sustainability companies - exhibit by 2009, distinct organizational processes compared to a matched sample of firms that adopted almost none of these policies - termed as Low Sustainability companies. We find that the boards of directors of these companies are more likely to be formally responsible for sustainability and top executive compensation incentives are more likely to be a function of sustainability metrics. Moreover, High Sustainability companies are more likely to have established processes for stakeholder engagement, to be more long-term oriented, and to exhibit higher measurement and disclosure of nonfinancial information. Finally, we provide evidence that High Sustainability companies significantly outperform their counterparts over the long-term, both in terms of stock market as well as accounting performance.
\end{abstract}

\footnotetext{
${ }^{*}$ Robert G. Eccles is a Professor of Management Practice at Harvard Business School. Ioannis Ioannou is an Assistant Professor of Strategy and Entrepreneurship at London Business School. George Serafeim is an Assistant Professor of Business Administration at Harvard Business School, contact email: gserafeim@ hbs.edu. Robert Eccles and George Serafeim gratefully acknowledge financial support from the Division of Faculty Research and Development of the Harvard Business School. We would like to thank Christopher Greenwald for supplying us with the ASSET4 data. Moreover, we would like to thank Cecile Churet and Iordanis Chatziprodromou from Sustainable Asset Management for giving us access to their proprietary data. We are grateful to Chris Allen, Jeff Cronin, Christine Rivera, and James Zeitler for research assistance. We thank Ben Esty, David Larcker (discussant), Joshua Margolis, Costas Markides, Jeremy Stein (discussant), Catherine Thomas, and seminar participants at Boston College, the NBER conference on the "Causes and Consequences of Corporate Culture", Cardiff University, Saint Andrews University, International Finance Corporation, Columbia University, INSEAD and the Business and Environment Initiative at Harvard Business School for helpful comments. We are solely responsible for any errors in this manuscript.
} 


\section{Introduction}

Neoclassical economics and several management theories assume that the corporation's objective is profit maximization subject to capacity (or other) constraints. The key agent in such models is the shareholder, acting as the ultimate residual claimant who provides the necessary financial resources for the firm's operations (Jensen and Meckling, 1976; Zingales, 2000). However, there is substantial variation in the way corporations actually compete and pursue profit maximization. Different corporations place more or less emphasis on the long-term versus the short-term (Brochet et al., 2011); care more or less about the impact of externalities from their operations on other stakeholders (Paine, 2004); focus more or less on the ethical grounds of their decisions (Paine, 2004); and assign relatively more or less importance on shareholders compared to other stakeholders (Freeman et al., 2007). For example, Southwest Airlines has identified employees and Novo Nordisk patients (i.e., their end customers) as their primary stakeholder.

During the last 20 years, a relatively small but growing number of companies have voluntarily integrated social and environmental issues in their business models and daily operations (i.e. their strategy) through the adoption of related corporate policies. ${ }^{1}$ Such integration of environmental and social issues into a company's business model raises a number of fundamental questions for scholars of organizations. Does the governance structure of firms that adopt environmental and social policies differ from that of other firms and, if yes, in what ways? Do such firms have distinct stakeholder engagement processes and adopt different time horizons for their decision-making? In what ways are their measurement and reporting systems different? Finally, what are the performance implications of integrating social and environmental issues into a company's strategy and operations?

Some scholars argue that companies can "do well by doing good" (Godfrey, 2005; Margolis et al., 2007; Porter and Kramer, 2011) based on the assumption that meeting the needs of other stakeholders - e.g. employees through investment in training - directly creates value for shareholders (Freeman et al., 2010, Porter and Kramer, 2011). It is also based on the assumption that by not meeting the needs of other stakeholders, companies can destroy shareholder value because of consumer boycotts (e.g., Sen et al., 2001), the inability to hire the most talented people (e.g., Greening and Turban 2000), and by paying potentially punitive fines to governments. On the other hand, other scholars argue that adopting environmental and social policies can destroy shareholder wealth (e.g., Friedman 1970; Clotfelter 1985; Navarro 1988; Galaskiewicz 1997). In its simplest form, their argument is that sustainability may simply be a type of agency cost: managers receive private benefits from embedding environmental and social

\footnotetext{
${ }^{1}$ During the same period many more companies were active in corporate social responsibility (CSR) as an ancillary activity. However, many of these companies did not necessarily implement or were unable to implement CSR as a central strategic objective of the corporation. Moreover, CSR has diffused broadly in the business world only in the last seven years (Eccles and Krzus, 2010).
} 
policies in the company' strategy, but doing so has negative financial implications for the organization (Baloti and Hanks 1999; Brown et al., 2006). Moreover, these companies might experience a higher cost structure (e.g. paying their employees living rather than market wages). Consequently, the argument continues, companies that do not operate under such additional environmental and social constraints will be more competitive and as a result, will be more successful in a highly competitive environment. In fact, this hypothesis is well captured in Jensen (2001) who states: "Companies that try to do so either will be eliminated by competitors who choose not to be so civic minded, or will survive only by consuming their economic rents in this manner." (p. 16).

In this study, we shed light on the organizational and performance implications of integrating social and environmental issues into a company's strategy and business model through the adoption of corporate policies. The overarching thesis of our work is that organizations that voluntarily integrate environmental and social policies in their business model represent a fundamentally distinct type of the modern corporation, characterized by a governance structure that in addition to financial performance, accounts for the environmental and social impact of the company, a long-term approach towards maximizing inter-temporal profits, an active stakeholder management process, and more developed measurement and reporting systems. Empirically, we identify 90 companies - we term these as High Sustainability companies - with a substantial number of environmental and social policies adopted for a significant number of years (since the early to mid-1990s), reflecting strategic choices that are independent and in fact, far preceded the current hype around sustainability issues (Eccles and Krzus, 2010). Subsequently, we use propensity score matching in 1993 to identify 90 comparable firms that adopted almost none of these policies; we term these as Low Sustainability companies. In the year of matching, the two groups operate in exactly the same sectors and exhibit statistically identical size, capital structure, operating performance, and growth opportunities. By generating matched pairs of firms as early as 1993, we are therefore able to not only focus on long-term organizational implications but also to introduce a long time lag between our independent and dependent variables, thus mitigating the likelihood of bias that could arise from reverse causality.

Consistent with our expectations, we find that the group of High Sustainability firms is significantly more likely to assign responsibility to the board of directors for sustainability and to form a separate board committee for sustainability. Moreover, they are more likely to make executive compensation a function of environmental, social, and external perception (e.g., customer satisfaction) metrics. This group is also significantly more likely to establish a formal stakeholder engagement process where risks and opportunities are identified, the scope of the engagement is defined ex ante, managers are trained in stakeholder engagement, key stakeholders are identified, results from the engagement process are reported both internally and externally, and feedback from stakeholders is given to the board of 
directors. This set of High Sustainability firms also appears to be more long-term oriented: they have an investor base with a larger proportion of long-term oriented investors and they communicate more longterm information in their conference calls with sell-side analysts. Since information is a crucial asset that a corporation needs to have for effective strategy execution by management, as well as the effective monitoring of this execution by the board, we find that High Sustainability firms are more likely to measure information related to key stakeholders such as employees, customers ${ }^{2}$, and suppliers - and to increase the credibility of these measures by using auditing procedures. We also find that High Sustainability firms not only measure but also disclose more nonfinancial (e.g., environmental, social, and governance) data. Our findings suggest that to a large extent the adoption of these sustainability policies reflects by 2009 their underlying institutionalization within and across the organization rather than reflecting acts undertaken as part of "greenwashing" and "cheap talk" (Marquis and Toffel, 2011).

Importantly, we show that there is significant variation in subsequent accounting and stock market performance across the two groups of firms in the long run. In particular, we track corporate performance for 18 years and find that High Sustainability firms outperform Low Sustainability firms both in stock market as well as accounting performance. Using a four-factor model to account for potential differences in the risk profile of the two groups, we find that annual abnormal performance is higher for the High Sustainability group compared to the Low Sustainability group by $4.8 \%$ (significant at less than $5 \%$ level) on a value-weighted base and by $2.3 \%$ (significant at less than $10 \%$ level) on an equal weighted-base. We find that High Sustainability firms also perform better when we consider accounting rates of return, such as return-on-equity (ROE) and return-on-assets (ROA) and that this outperformance is more pronounced for firms that sell products to individuals (i.e., business-to-customer [B2C] companies), compete on the basis of brand and reputation, and make substantial use of natural resources. Finally, using analyst forecasts of annual earnings we find that the market underestimated the future profitability of the High Sustainability firms compared to the Low Sustainability ones.

\section{Sample Selection and Summary Statistics}

To understand the effects of integrating social and environmental issues in an organization's business model, we first need to identify companies that have explicitly placed a high level of emphasis on employees, customers, products, the community, and the environment as part of their strategy and business model. Moreover, we need to find firms that have adopted these policies for a significant number of years prior to CSR becoming widespread, to reduce the possibility of potential measurement error due to the inclusion of firms that are either "greenwashing" or adopting these policies purely for public relations and communications reasons. Finally, by identifying firms based on policy adoption decisions that were made a sufficiently long time ago - thus introducing a long lag between our independent and

\footnotetext{
${ }^{2}$ Although we find directionally consistent results for customers, our results are not statistically significant.
} 
dependent variables - we mitigate the likelihood of biases that could potentially arise from reverse causality.

We identify two groups of firms: those that have and those that have not adopted a comprehensive set of corporate policies related to the environment, employees, community, products, and customers. The complete set of these policies is provided in the Appendix. Examples of policies related to the environment include whether the company has a policy to reduce emissions, uses environmental criteria in selecting members of its supply chain, and whether the company seeks to improve its energy or water efficiency. Policies related to employees include whether the company has a policy for diversity and equal opportunity, work-life balance, health and safety improvement, and favoring internal promotion. Policies related to community include corporate citizenship commitments, business ethics, and human rights criteria. Policies related to products and customers include product and services quality, product risk, and customer health and safety. The Thomson Reuters ASSET4 database, which has already been used in the literature (Cheng, Ioannou and Serafeim, 2012; Ioannou and Serafeim, 2012), provides data on the adoption or non-adoption of these policies, for at least one year, for 775 US companies in fiscal years 2003 to $2005 .{ }^{3}$ We eliminate 100 financial institutions, such as banks, insurance companies, and finance firms, because their business model is fundamentally different and many of the environmental and social policies are not likely to be applicable or material to them. For the remaining 675 companies we construct an equal-weighted index of all policies (Sustainability Policies) that measures the percentage of the full set of identified policies that a firm is committed to in each year.

Moreover, we track over time the extent of adoption of these policies for those organizations that score at the top quartile of Sustainability Policies. We do so by reading published reports, such as annual and sustainability reports, and visiting corporate websites to understand the historical origins of the adopted policies. Furthermore, we conducted more than 200 interviews with corporate executives to validate the historical adoption of these policies. At the end of this process, we were able to identify 90 organizations that adopted a substantial number of these policies in the early to mid-90s. We label this set of firms as the High Sustainability group. Of the remaining 78 firms, 70 firms adopted these policies gradually over time mostly after 1999. For eight firms we were unable to identify the historical origins of these policies. The High Sustainability group had adopted by the mid-90s on average $40 \%$ of the policies identified in the Appendix, and by the late 2000s almost 50\%. Subsequently, we match each of the firms in the High Sustainability group with a firm that scores in the lowest two quartiles of Sustainability

\footnotetext{
${ }^{3}$ Founded in 2003, ASSET4 was a privately held Swiss-based firm, acquired by Thomson Reuters in 2009. The firm collects data and scores firms on environmental and social dimensions since 2002. Research analysts of ASSET4 collect more than 900 evaluation points per firm, where all the primary data used must be objective and publicly available. Typical sources include stock exchange filings, annual financial and sustainability reports, nongovernmental organizations' websites, and various news sources. Every year, a firm receives a z-score for each of the pillars, benchmarking its performance with the rest of the firms in the database.
} 
Policies. Firms in those two quartiles have, on average, adopted only $10 \%$ of the policies, even by the late 2000s. These same firms had adopted almost none of these policies in the mid-90s. Because we require each firm in the High Sustainability group to be in existence since at least the early 1990s, we impose the same restriction for the pool of possible control firms. After this filter, the available pool of control firms is 269 .

We implement a propensity score matching process to produce a group of control firms that looks as similar as possible to our High Sustainability group. The match is performed in 1993 because this is the earliest year that we can confirm any one of the firms included in the High Sustainability group had adopted these policies. To ensure that our results are not particularly sensitive to the year we choose for the matching procedure, we redo the matching in 1992 and 1994. In any one year less than 5\% of the matched pairs change, suggesting that the year we choose for matching does not affect our final sample set. We match each High Sustainability firm with a control firm that is in the same industry classification benchmark subsector (or sector if a firm in the same subsector is not available), by requiring exact matching for the sector membership. We use as covariates in the logit regression the natural logarithm of total assets (as a proxy for size), $\mathrm{ROA}^{4}{ }^{4}$ asset turnover (measured as sales over total assets), market value of equity over book value of equity (MTB), as a proxy for growth opportunities, and leverage (measured as total liabilities over total assets). We use propensity score matching without replacement and closest neighbor matching. ${ }^{5}$ Size and asset turnover load with a positive and highly significant coefficient in the logit regression (untabulated results). The coefficient on MTB is positive and weakly significant. The coefficients on leverage and ROA are both insignificant. We label the set of control firms that are selected through this process as the Low Sustainability group.

Table 1 Panel A, shows the sector composition of our sample and highlights that a wide range of sectors are represented. Panel B shows the average values of several firm metrics across the two groups in the year of matching. The High Sustainability group has on average, total assets of $\$ 8.6$ billion, $7.86 \%$ ROA, 11.17\% ROE, 56\% leverage, 1.02 turnover, and 3.44 MTB. Similarly, the matched firms (i.e., the Low Sustainability group) have on average, total assets of $\$ 8.2$ billion, $7.54 \%$ ROA, $10.89 \%$ ROE, 57\% leverage, 1.05 turnover, and 3.41 MTB. None of the differences in the averages across the two groups are statistically significant, suggesting that the matching process worked effectively. The two groups are statistically identical in terms of sector membership, size, operating performance, capital structure, and

\footnotetext{
${ }^{4}$ We also used ROE as a measure of performance and all the results were very similar to the results reported in this paper. We also included other variables such as stock returns over the past one, two or three years but none of them was significant.

${ }^{5}$ Using a caliper of 0.01 to ensure that none of the matched pairs is materially different reduces our sample by two pairs or four firms. All our results are unchanged if we use that sample of 176 firms.
} 
growth opportunities. Moreover, the two groups have very similar risk profiles: both the standard deviation of daily returns and the equity betas are approximately equal.

\section{Corporate Governance}

The responsibilities of the board of directors and the incentives provided to top management are two fundamental attributes of the corporate governance system. Boards of directors perform a monitoring and advising role and ensure that management is making decisions in a way that is consistent with organizational objectives. Top management compensation systems align managerial incentives with the goals of the organization by linking executive compensation to key performance indicators that are used for measuring corporate performance (Govindarajan and Gupta, 1985). Ittner, Larcker, and Rajan (1997) showed that the use of nonfinancial metrics in annual bonus contracts is consistent with an "informativeness" hypothesis, where nonfinancial metrics provide incremental information regarding the manager's action choice.

Therefore, we posit that for organizations that consider environmental and social objectives as core issues for their strategy and operations, the board of directors is more likely to have direct responsibility over such issues; it is also more likely that top management compensation will be a function of sustainability metrics in addition to other traditional financial performance metrics. To test these predictions we analyze proprietary data provided to us by Sustainable Asset Management (SAM). SAM collects the relevant data and constructs the Dow Jones Sustainability Index. Once a year, SAM initiates and leads an independent sustainability assessment of approximately 2,250 of the largest corporations around the world. The SAM Corporate Sustainability Assessment is based on the annual SAM Questionnaire, which consists of an in-depth analysis based on approximately 100 questions on economic, environmental, and social issues, with a particular focus on companies' potential for long-term value creation. The questionnaire is designed to ensure objectivity by limiting qualitative answers through predefined multiple-choice questions. In addition, companies must submit relevant information to support the answers provided. The SAM Questionnaires are distributed to the CEOs and heads of investor relations of all the companies in the starting universe. The completed company questionnaire, signed by a senior company representative, is the most important source of information for the assessment.

Table 2, Panel A shows the governance data items that SAM provided to us for fiscal year 2009, as they relate to the board of directors and the executives' incentive systems. We find results that are consistent with our predictions. Fifty three percent of the firms in the High Sustainability group assign formal responsibility around sustainability to the board of directors. In contrast, only $22 \%$ of the firms in the Low Sustainability group hold the board accountable for sustainability. Similarly, 41\% (15\%) of the firms in the High Sustainability group (Low Sustainability group) form a separate board committee that deals with sustainability issues. The responsibilities and duties of a sustainability committee include both 
assisting the management with strategy formulation and reviewing periodically sustainability performance. For example, the principal functions of the sustainability committee of the Ford Corporation include assisting management in the formulation and implementation of policies, principles, and practices to foster the sustainable growth of the company on a global basis and to respond to evolving public sentiment and government regulation in the area of $\mathrm{GHG}$ emissions and fuel economy and $\mathrm{CO}_{2}$ regulation. Other functions include assisting management in setting strategy, establishing goals, and integrating sustainability into daily business activities, reviewing new and innovative technologies that will permit the company to achieve sustainable growth, reviewing partnerships and relationships that support the company's sustainable growth, and reviewing the communication and marketing strategies relating to sustainable growth.

Another important governance feature is the set of metrics that are linked to senior executive compensation. The two groups differ significantly on this dimension as well: High Sustainability firms are more likely to align senior executive incentives with environmental, social, and external (i.e., customer) perception performance metrics, in addition to financial metrics. Of the firms in the High Sustainability group, $18 \%, 35 \%$, and $32 \%$ link compensation to environmental, social, and external perception metrics, respectively. In contrast, only $8 \%, 22 \%$, and $11 \%$ of the firms in the Low Sustainability group link compensation to environmental, social, and external perception metrics. Firms in the High Sustainability group are more likely to use monetary incentives to help executives focus on nonfinancial aspects of corporate performance that are important to the firm. For example, Intel has linked executive compensation to environmental metrics since the mid-90s, and since 2008 Intel links all employees' bonuses to environmental metrics. The 2010 metrics focused on carbon emission reductions in Intel's operations and energy-efficiency goals for new products. While the environmental component represents a relatively small portion of the overall employee bonus calculation, Intel believes that it helps focus employees on the importance of achieving its environmental objectives.

Moreover, in Panel B we present results from a multivariate analysis of these governance mechanisms. To avoid results overload, we construct a variable that summarizes all the mechanisms discussed in Panel A by calculating the percentage of mechanisms that a firm has adopted. Because the firms might look considerably different in terms of size, growth opportunities, and performance at 2009, we control for these factors in our model by measuring them at the end of 2009. Consistent with the results above, we find that firms in the High Sustainability group adopt significantly more of the mechanisms described in Panel A: the coefficient on High Sustainability is positive and significant $(0.144$, p-value $=0.006)$. Larger firms and more profitable firms have more of these mechanisms, whereas growth opportunities are not related to their adoption. Overall, the results suggest that firms included in the High Sustainability group are characterized by a distinct governance structure: responsibility over 
sustainability is more likely to be directly assigned to the board of directors and top management compensation is also more likely to be a function of a set of performance metrics that critically includes sustainability metrics.

\section{Stakeholder Engagement}

Since High Sustainability firms are characterized by a distinct corporate governance model that focuses on a wider range of stakeholders as part of their corporate strategy and business model, we predict that such firms are also more likely to adopt a greater range of stakeholder engagement practices. This is because engagement is necessary for understanding these stakeholders' needs and expectations in order to make decisions about how best to address them (Freeman, 1984; Freeman et al., 2007). With regards to stakeholder management, prior literature has suggested and empirically shown that it is directly linked to superior financial performance by enabling firms to develop intangible assets in the form of strong longterm relationships, which can become sources of competitive advantage (e.g., Hillman and Keim, 2001). In other words, superior stakeholder engagement is fundamentally based on the firm's ability to establish such relationships with key stakeholders over time. Similarly, it has been argued that when a corporation is able to credibly commit to contracting with its stakeholders on the basis of mutual trust and cooperation and a longer-term horizon - as opposed to contracting in an attempt to curb opportunistic behavior - then the corporation "will experience reduced agency costs, transactions costs, and costs associated with team production" (Jones, 1995; Foo, 2007; Cheng et al., 2011). We argue therefore, that firms that have embedded the elements of mutual trust and cooperation and the building of long-term relationships with key stakeholders through the incorporation of social and environmental issues in their strategy and business model will be better positioned to pursue these more efficient forms of contracting (Jones, 1995). On the other hand, firms that have not integrated social and environmental issues are more likely to contract on the basis of curbing opportunistic behavior and this will impede their ability to adopt a broad range of stakeholder engagement practices.

To get a better understanding of the differences in the stakeholder engagement model across the two groups of firms in our sample, we again use proprietary data obtained through SAM. Panel A of Table 3 presents a comparison between the High and Low Sustainability firms across several data items that relate to actions prior to, during, and after stakeholder engagement. In particular, each item in Table 3 measures the frequency of adoption of the focal practice within each of the two groups, and the last column presents a significance test of the differences between them. As before, the data are for the fiscal year of 2009. We find that High Sustainability firms are more likely to adopt practices of stakeholder engagement for all three phases of the process (prior to, during, and after) compared to Low Sustainability ones. 
Prior to the stakeholder engagement process, High Sustainability firms are more likely to train their local managers in stakeholder management practices (14.9\% vs. $0 \%$, Training), and to perform their due diligence by undertaking an examination of costs, opportunities, and risks $(31.1 \%$ vs. $2.7 \%$, Opportunities Risks Examination). Moreover, High Sustainability firms are more likely to identify issues and stakeholders that are important for their long-term success $(45.9 \%$ vs. $10.8 \%$, Stakeholder Identification). During the stakeholder engagement process itself, our analysis shows that High Sustainability firms are more likely to ensure that all stakeholders raise their concerns $(32.4 \%$ vs. $2.7 \%$, Concerns) and to develop with their stakeholders a common understanding of the issues relevant to the underlying issue at hand (36.5\% vs. $13.5 \%$, Common Understanding). In addition, they are more likely to mutually agree upon a grievance mechanism with the stakeholders involved (18.9\% vs. $2.7 \%$, Grievance Mechanism) and to agree on the targets of the engagement process (16.2\% vs. $0 \%$, Targets).Moreover, High Sustainability firms are more likely to pursue a mutual agreement on the type of engagement with their stakeholders (36.5\% vs. $8.1 \%$, Scope Agreement).

Finally, we find that after the completion of the stakeholder engagement process, High Sustainability firms are more likely to provide feedback from their stakeholders directly to the board or other key departments within the corporation (32.4\% vs. $5.4 \%$, Board Feedback), and are more likely to make the results of the engagement process available to the stakeholders involved $(31.1 \%$ vs. $0 \%$, Result Reporting) and the broader public (20.3\% vs. 0\%, Public Reports). In sum, High Sustainability firms appear to be more proactive, more transparent, and more accountable in the way they engage with their stakeholders.

Moreover, in Panel B we present results from a multivariate analysis of these stakeholder engagement mechanisms. Similar to Section 3, we construct a variable that summarizes all the mechanisms discussed in Panel A by calculating the percentage of mechanisms that a firm has adopted. Consistent with the results above, we find that firms in the High Sustainability group adopt significantly more of the stakeholder engagement mechanisms described in Panel A. In general, the results of this section confirm our predictions: High Sustainability firms are distinct in their stakeholder engagement model in that, compared to the Low Sustainability firms they are more focused on understanding the needs of their stakeholders, making investments in managing these relationships, and reporting internally and externally on the quality of their stakeholder relationships.

\section{Time Horizon}

The previous section argued for a distinct stakeholder management model and provided evidence for the adoption of a wider range of stakeholder engagement practices. In assessing the impact of stakeholder engagement, previous literature has argued that the effective management of stakeholder relationships can generate persistence of superior financial performance over the longer-term, or in the faster recovery of 
poorly performing firms (Choi and Wang, 2009). This occurs because building good stakeholder relations as part of a corporation's strategy, takes time to materialize, is idiosyncratic to each corporation, and depends on its history; such relationships are based on mutual respect, trust, and cooperation and take time to develop. In other words, effective stakeholder engagement necessitates the adoption of a longerterm time horizon.

To date, the extant literature on "short-termism" (e.g., Laverty, 1996) has shown that executive compensation incentives that are based on short-term metrics may push managers towards making decisions that deliver short-term performance at the expense of long-term value creation. Consequently, a short-term focus on creating value may result in a failure to make the necessary strategic investments to ensure future profitability. Importantly, such a short-term approach to decision-making often implies a negative externality being imposed on various other key stakeholders. In other words, short-termism is incompatible with extensive stakeholder engagement and a focus on stakeholder relationships. It is also true then that the pathologies of short-termism are less likely to be suffered by corporations with a clear focus and commitment to multiple stakeholders. Given the documented commitment of High Sustainability firms to stakeholder engagement therefore, we further predict that they are more likely to adopt such a longer-term approach, and that this approach will also be reflected in the type of investors that are attracted to such corporations. ${ }^{6}$

In Panel A of Table 4 we empirically test whether High Sustainability firms are focused more on a longer-term horizon in their communications with analysts and investors. A company communicates its norms and values both internally and externally, and since a long-term time horizon is one key element of integrating social and environmental issues into strategy, we would expect High Sustainability firms to put greater emphasis on the long-term than the Low Sustainability ones do. Investors that are interested in generating short-term results by selling their stock after it has (hopefully) appreciated will avoid investing in long-term-oriented firms since these firms are willing to sacrifice such short-term results if doing so will produce long-term gains. In contrast, investors who plan to hold a stock for a long period of time will be attracted to firms that are optimizing financial performance over a longer time horizon and are less interested in short-term performance fluctuations. For example, after Paul Polman became the CEO of Unilever and announced the implementation of the Sustainable Living Plan while abolishing quarterly earnings reports, ownership of Unilever's stock by hedge funds dropped from $15 \%$ to $5 \%$ in three years,

\footnotetext{
${ }^{6}$ We acknowledge that under some conditions the reverse may be true: investor behavior may be driving managerial decision-making. However, in the case of sustainability policies, we argue that this is rather unlikely. Since stakeholder relations take several years to build, the probability of a large enough shareholder base retaining ownership for a sufficiently long amount of time in order to institute a radical corporate change towards sustainability seems low. This line of argument would also require investors to themselves engage with the company over a long period of time in such a way as to establish a culture of more long-term thinking which in turn, would push the corporation towards better shareholder and other stakeholder engagement.
} 
which led to reduced fluctuations in the company's share price. To test our predictions, we use data from Thomson Reuters Street Events to measure the extent to which the content of the conversations between a focal corporation and sell-side analysts is comprised of long-term vs. short-term keywords. We construct this measure following the methodology in Brochet, Loumioti, and Serafeim (2012), as the ratio of the number of keywords used in conference calls that characterize time periods of more than one year over the number of keywords that characterize time periods of less than one year. Second, we measure the time horizon of the investor base of a corporation following Bushee (2001) and Bushee and Noe (2000), by calculating the percentage of shares outstanding held by "dedicated" vs. "transient" investors. Bushee (2001) classifies institutional investors using a factor and a cluster analysis approach. Transient investors have high portfolio turnover and highly diversified portfolios. In contrast, dedicated investors have low turnover and more concentrated holdings. We measure how long-term oriented the investor base of a firm is by calculating the difference between the percentage of shares held by dedicated investors and the percentage of shares held by transient investors.

The results presented in Table 4 are consistent with our predictions. We find that High Sustainability firms are more likely to have conference call discussions with analysts whose content is relatively more long-term as opposed to short-term focused (1.08 vs. 0.96, Long-term vs. Short-term Discussion). In addition, High Sustainability firms are significantly more likely to attract dedicated rather than transient investors (-2.29 vs. -5.31, Long-term vs. Short-term Investors). In Panel B of Table 4 we present results from a multivariate analysis of these long-term oriented behaviors and characteristics and we find consistent results. In sum, our findings suggest that High Sustainability firms are effective communicators of their long-term approach: not only do they speak in those terms but in fact, they are convincing long-term investors to invest in their stock.

\section{Measurement and Disclosure}

\section{Measurement}

Performance measurement is essential for management to determine how well it is executing on its strategy and to make any necessary corrections (Kaplan and Norton, 2008). The quality, comparability, and credibility of information are enhanced by internal and external audit procedures that verify the accuracy of this information or the extent to which practices are being followed. Given that High Sustainability firms place a greater emphasis on stakeholder engagement than the Low Sustainability firms, we would expect the same to be true for particular key stakeholder groups including employees, customers, and suppliers. In particular, we would expect the High Sustainability firms to place significantly more emphasis on measuring and monitoring performance, auditing performance measures, adherence to standards, and reporting on performance. Using the proprietary SAM data described in Section 4 , we are able to test for differences in the extent to which the two groups of firms measure, audit, 
and report on their performance as it relates to these three stakeholder groups. Table 5 presents a comparison between the High and Low Sustainability firms for Employees (Panel A), Customers (Panel B), and Suppliers (Panel C). Similar to the results of previous sections, each of these three panels measures the frequency of adoption of the focal practice within each of the two groups, and the last column presents a significance test of the differences between them.

For Employees, we find significant differences on three of the four metrics. High Sustainability firms are significantly more likely to measure execution of skill mapping and development strategy (54.1\% vs. $16.2 \%$, HR Performance Indicators/Nonfinancial), the number of fatalities in company facilities (77.4\% vs. $26.3 \%$, KPI Labor/EHS Fatalities Tracking), and the number of "near misses" on serious accidents in company facilities (64.5\% vs. $26.3 \%$, KPI Labor/EHS Near Miss Tracking). We find no significant difference between the two groups for the percentage of companies that use health and safety performance tracking to follow labor relations issues. This may be due to laws and regulations requiring all firms to perform such measures (e.g., as required by the Occupational Health and Safety Administration [OSHA]), thereby leveling the field and eliminating any potential differences that could have been in place under conditions where such laws and regulations did not exist; the high percentages for both groups indicate that this might be the case $(95.2 \%$ vs. $89.5 \%$, KPI Labor / EHS Performance Tracking). These results therefore, reflect the greater commitment that High Sustainability firms make to the employee stakeholder group.

Panel B focuses on Customers and shows the frequency of adoption of seven relevant practices. Contrary to our expectations and in contrast to our findings regarding Employees, there is virtually no difference between High Sustainability and control firms on any one of these metrics, although across all metrics more firms in the High Sustainability group measure customer-related data. We note that across both groups a very small percentage of firms have adopted these metrics. If anything, one could argue that the relationship between effective engagement and the creation of shareholder value is even more direct for Customers than it is for Employees; yet even in the High Sustainability group, very few are measuring the quality of this relationship. We suggest that one possible reason for this could be the rather primitive state of customer relationship management practices. Moreover, our data seem to suggest that these results are linked to the ease with which these practices can be measured. For example, variables like Cost of Service and Potential Lifetime Value are very difficult to measure with only $6.8 \%$ and $8.1 \%$, respectively, of the High Sustainability firms measuring this variable. The highest percentages for this group are for Geographical Segmentation (18.9\%), Customer Generated Revenues (18.9\%), and Historical Sales Trends (16.2\%) which are relatively easier to measure.

In contrast to Customers, there are some significant differences between the two groups of firms in terms of Suppliers. In particular, we examine the standards used to select and manage relationships 
with Suppliers, which can determine the quality of the relationship they have with the firm. Panel C shows the frequency of adoption of 11 related practices: six of these are strongly and significantly different across the two groups with $\mathrm{p}$-values of $<0.001$, and the rest are significantly different at $\mathrm{p}$-values $<0.06$. These standards fall into either environmental or social issues, or a combination of the two. In terms of environmental issues, significantly more High Sustainability firms use environmental monitoring systems in the certification/audit/verification process (50.0\% vs. $18.2 \%$, Environmental Management Systems), environmental data availability by the supplier $(12.3 \%$ vs. $0.0 \%$, Environmental Data Availability), the supplier's environmental policies (17.4\% vs. $0.0 \%$, Environmental Policy), and the supplier's environmental production standards (45.6\% vs. $25.7 \%$, Environmental Production Standards) in selecting and evaluating suppliers than do Low Sustainability firms. Similarly, on social issues for selecting and evaluating suppliers, significantly more High Sustainability firms use human rights standards such as forced labor, slave labor, and child labor (17.4\% vs. 5.7\%, Human Rights Standards), labor standards/requirements (18.6\% vs. $8.1 \%$, Labor Standards), and occupational, health, and safety standards (62.9\% vs. 25.7\%, OHS Standards). Finally, High Sustainability Firms make a greater use of compliance to general standards, both international $(12.3 \%$ vs. $0.0 \%$, International Standards Compliance) and domestic (14.9\% vs. $8.1 \%$, National Standards Compliance), in selecting and evaluating Suppliers.

The reliability and credibility of performance measurement is enhanced when it is subject to some form of objective, third-party audit or assurance. The purpose of an audit is to ensure that the appropriate measurement standards have been applied and that the internal control and measurement systems producing information according to these standards, are robust. Companies can also perform internal audits whereby a separate department is responsible for verifying the numbers produced by another department. With rare exceptions, an external or internal audit or assurance opinion is not required for reported nonfinancial information on a company's environmental and social performance. However, given the greater importance that High Sustainability firms accord to nonfinancial metrics (e.g., linking executive compensation to such metrics), we predict a greater use of assurance by High Sustainability firms than Low Sustainability firms.

Panel D shows the frequency of adoption of 13 focal practices regarding the use of internal and external audit and assurance procedures. For the most part, the results are marginally significant but the one case where our hypothesis does get clear support is having an external third-party conduct an audit of the company's corporate sustainability report which reports on its environmental, social, and governance performance ( $11.1 \%$ vs. $1.4 \%$, Sustainability report external audit), with a p-value of 0.017 . The only other item that has any degree of statistical significance is when the company bases its performance measurement on relevant external standards and programs, such as AccountAbility's AA 1000 standard 
and the Global Reporting Initiative's G3 Guidelines; 16.2\% of the High Sustainability firms do this, in contrast to only $2.7 \%$ of the Low Sustainability ones.

We note that very few of the High Sustainability firms have implemented assurance practices: of the 11 focal items in Panel D the highest percentage for the High Sustainability firms is $16.2 \%$. There are a number of reasons for why assurance procedures are so uncommon. Technologies for measuring and auditing nonfinancial information are still in their infancy and remain at a relatively primitive state of development compared to financial information (Simnett, Vantraelen, and Chua, 2009). This is not surprising given that external reporting of such information only started about 10 years ago, has only received a significant level of interest in the past five years, and even today only a small percentage of companies are reporting this information. One of the most important and difficult to overcome barriers to auditing nonfinancial information includes the lack of an agreed-upon set of measurement standards. This in turn, makes it very difficult to create auditing standards. Another barrier is the lack of sophisticated information technology systems for measuring nonfinancial performance, especially compared to the sophisticated and robust systems developed for financial reporting. Three other barriers are important to note. First, traditional audit firms are in the early stages of developing the capabilities to audit nonfinancial information. This, combined with the lack of standards and IT systems, creates the second barrier, which is a concern that performing this function will increase their legal risk beyond the amount they already face for performing financial audits. Third, firms which do have capabilities for auditing nonfinancial information, such as engineering firms for environmental information and human resource supply chain consultants for social information, lack the global scale and full range of capabilities that would be required to serve a large corporation that wants a single group to perform this audit. While a large number of boutique firms could be hired to do this, the aggregate transaction and coordination costs would be high.

Finally, in Panel E we present results from a multivariate analysis of nonfinancial measurement and assurance mechanisms. Similar to prior sections, we construct a variable that summarizes all the mechanisms discussed in Panels A through D by calculating the percentage of mechanisms that a firm has adopted within each of the stakeholder groups, and with regards to assurance. Consistent with the results above, we find that firms in the High Sustainability group adopt significantly more of the nonfinancial measurement practices described in Panels A-D: the coefficients on High Sustainability are positive and significant for Employees and Suppliers (but not for Customers), and the same is true for the assurance dimension.

Disclosure

Another important element is the extent to which a company is willing to be transparent in its external reporting about its environmental and social impact. Reporting on such nonfinancial performance 
measures to the board is an essential element of corporate governance so that the board can form an opinion about whether management is executing the strategy of the organization well. Moreover, external reporting of performance improves managerial accountability to shareholders and other stakeholders. Therefore, we expect High Sustainability firms to be more transparent and to exhibit a better balance between financial and nonfinancial information in their external reporting. We test this prediction in Panel A of Table 6 based on four focal metrics. First, we use ESG Disclosure scores, calculated by both Bloomberg and Thomson Reuters; it is a measure of how complete the company's reporting is on a range of environmental, social, and governance topics based on a scale of $0 \%$ to $100 \%$. Table 6 compares the (average) percentages of High and Low Sustainability firms. The average Bloomberg ESG Disclosure score for High Sustainability firms is $29.90 \%$, compared to $17.86 \%$ for the Low Sustainability ones. The corresponding percentages for the Thomson Reuters ESG Disclosure score are $46.38 \%$ and $36.91 \%$, respectively. The Thomson Reuters ESG disclosure score screens fewer data points for the presence of disclosure, and that is why firms tend to have better disclosure under this score. Both of these differences are statistically significant across the two groups. We also compared the two groups in terms of the percentage of firms whose sustainability reports cover their entire global activities, using Thomson Reuters ASSET4 data. A more global report represents a higher level of transparency and accountability than one focused only on a company's home country. We again find a statistically significant difference: $41.1 \%$ of the High Sustainability firms have a global sustainability report compared to only $8.31 \%$ of the Low Sustainability firms.

Using data provided by SAM, we also tested whether High Sustainability firms are more likely to integrate environmental and social information with their financial reporting. Integration of environmental and social information in financial reports is increasingly being advocated as a way to ensure that corporations are held accountable for their impact on the environment and society (Eccles and Krzus, 2010) and in fact, it was recently mandated in South Africa. We find that $25.7 \%$ of the High Sustainability firms integrate social information and $32.4 \%$ integrate environmental information. In contrast, $5.4 \%$ of the Low Sustainability firms integrate social information and $10.8 \%$ integrate environmental information. Moreover, we analyzed the difference in the balance between financial and nonfinancial discussion in conference calls, using the Thomson Reuters Street Events conference call database described in Section 4. We classified all words referring to items captured by the accounting system and the stock market system as financial. We classified words that would typically be found in a balanced scorecard (Kaplan and Norton, 1996), except for financial keywords, as nonfinancial. ${ }^{7}$ Then we

\footnotetext{
${ }^{7}$ We identified 38 keywords as nonfinancial. Examples include customer, employee, supplier, risk management, reputation, leadership, strategy, and brand. We identified 155 keywords as financial. Examples include sales, earnings, gross margin, and cash flow.
} 
constructed a ratio that measures the number of nonfinancial keywords over financial keywords. The average ratio for the High Sustainability firms is 0.96, suggesting that on average these firms are using an equal number of financial and nonfinancial keywords in their discussion with the investment community. In contrast, the average ratio for the Low Sustainability firms is 0.68 , suggesting that on average these firms are discussing less frequently about nonfinancial aspects of the business such as employees, customers, suppliers, and products.

Finally, in Panel B of Table 6 we present results from a multivariate analysis (OLS and logistic models as appropriate) of these nonfinancial disclosure mechanisms. We use the variables from Panel A as our dependent variables and we control for firm size, growth opportunities, and performance measured at the end of 2009, as before. Consistent with the results above, we find that firms in the High Sustainability group adopt significantly more of the nonfinancial mechanisms described in Panel A: the coefficients on High Sustainability are positive and highly significant for all our specifications.

\section{Corporate Performance}

A question that we haven't yet addressed in our study is whether firms in the High Sustainability group under or outperform their counterparts in the Low Sustainability group. On the one hand, firms in the High Sustainability group might underperform because they experience high labor costs by providing excessive benefits to their employees, forego valuable business opportunities that do not fit their values and norms (such as selling products with adverse environmental consequences), and denying to pay bribes to gain business in corrupt countries where bribe payments are the norm. In other words, High Sustainability companies face tighter constraints in how they can behave. Since firms are trying to maximize profits subject to capacity constraints, tightening those constraints further can lead to lower profitability.

On the other hand, firms in the High Sustainability group might outperform the control firms because they are able to attract better human capital, establish more reliable supply chains, avoid conflicts and costly controversies with nearby communities (i.e., maintain their license to operate), and engage in more product and process innovations in order to be competitive under the constraints that the integration of social and environmental issues places on the organization. For example, Philips has translated its environmental commitments to product innovation around energy-efficient light bulbs and developing solar-power lighting in sub-Saharan Africa. Similarly, as of 2010 , Siemens had over $€ 20$ billion in revenues coming from its environmental portfolio.

Empirical examinations of the link between sustainability and corporate financial performance have resulted in contradictory findings, ranging from a positive to a negative to a U-shaped, or even to an inverse-U shaped relation (Margolis and Walsh, 2003). According to McWilliams and Siegel (2001), conflicting results are due to "several important theoretical and empirical limitations" (p.603) of prior 
studies; others have argued that prior work suffered from "stakeholder mismatching" (Wood and Jones, 1995), the neglect of "contingency factors" (e.g. Ullmann, 1985), "measurement errors" (e.g. Waddock and Graves, 1997) and omitted variable bias (Aupperle et al., 1985; Cochran and Wood, 1984; Ullman, 1985). Importantly, none of these studies has measured financial performance over long periods of time to allow for superior sustainability performance to impact either positively or negatively on financial performance.

To delve into the performance implications of integrating social and environmental issues into a company's strategy and business model we track the stock market performance of firms in both groups from 1993 to 2010. The use of stock returns addresses concerns over reverse causality in the absence of private information. In the presence of private information, reverse causality is a concern. For example, if managers with private information that their firms are going to outperform in the future adopt environmental and social policies today, then the expectation of higher stock returns is causing the adoption of these policies. However, we believe that this explanation is unlikely for a number of reasons. First, we are not aware of a theory suggesting that managers expecting to outperform market expectations in the future would be more likely to adopt environmental and social policies today. More importantly, empirical evidence suggests that managers are unable to forecast returns past 100 days (Jenter, Lewellen, and Warner, 2011). Therefore, accurately forecasting returns over the next 3, 5, or 10 years is rather unlikely, or even infeasible.

Figure 1 (2) shows the cumulative stock market performance of value-weighted (equal-weighted) portfolios for the two groups. Both figures document that firms in the High Sustainability group significantly outperform firms in the Low Sustainability group. Investing \$1 in the beginning of 1993 in a value-weighted (equal-weighted) portfolio of High Sustainability firms would have grown to \$22.6 (\$14.3) by the end of 2010. In contrast, investing \$1 in the beginning of 1993 in a value-weighted (equalweighted) portfolio of control firms would have only grown to $\$ 15.4$ (\$11.7) by the end of 2010. Table 7 presents estimates from a four-factor model that controls for the market, size, book-to-market, and momentum factors. We find that both portfolios exhibit statistically significant positive abnormal performance relative to the market. However, we note that this might be because for both samples we have chosen companies that survived and operated throughout the early 1990s and until the late 2000s. The better performance of the firms in both samples compared to the rest of the market may be attributed, to a considerable extent, to this survivorship bias. However, the relative performance difference between the two groups is not affected by this bias since both groups are equally likely to have survived, by construction of our sample. Accordingly, we find that the annual abnormal performance is higher for the High Sustainability group compared to the Low Sustainability group by $4.8 \%$ (significant at less than 5\% level) on a value-weighted base and by $2.3 \%$ (significant at less than $10 \%$ level) on an equal-weighted 
base.In fact, when we examine the performance of the two portfolios, we find that The High Sustainability portfolio outperforms the control portfolio in 11 out of the 18 years. In addition, the High Sustainability portfolio exhibits lower volatility. Whereas the standard deviation of monthly abnormal returns is $1.43 \%$ and $1.72 \%$ on a value-weighted and equal-weighted base, respectively for the High Sustainability group, the corresponding estimates for the Low Sustainability group are $1.72 \%$ and $1.79 \%$.

To ensure that our results are not driven by long-run mean reversion in equity prices (Poterba and Summers, 1988) or accounting profitability (Fama and French, 2000), we also examine the performance of the two groups for the three years before 1993 (untabulated). We find that the two groups exhibit very similar performance throughout these three years: cumulative stock returns are higher for the High Sustainability group by only $1 \%$. Similarly, cumulative ROA is higher for the Low Sustainability group by only $0.04 \%$, and cumulative ROE is higher for the High Sustainability group by $0.03 \%$. This result is consistent with our previous finding that matching in any one of the years between 1990 and1993 has little impact on the composition of the pairs.

Overall, we find evidence that firms in the High Sustainability group are able to significantly outperform their counterparts in the Low Sustainability group. This finding suggests that companies can adopt environmentally and socially responsible policies without sacrificing shareholder wealth creation. In fact, the opposite appears to be true: High Sustainability firms generate significantly higher stock returns, suggesting that indeed the integration of such issues into a company's business model and strategy may be a source of competitive advantage for a company in the long-run. A more engaged workforce, a more secure license to operate, a more loyal and satisfied customer base, better relationships with stakeholders, greater transparency, a more collaborative community, and a better ability to innovate may all be contributing factors to this potentially persistent superior performance in the long-term.

Sector Analysis

To shed some light on the underlying mechanisms that generate this outperformance, we construct a cross-sectional model where the dependent variable is the alpha for each firm from the four-factor model and the independent variable is an indicator variable for whether a firm is a member of the High Sustainability group. We interact this variable with three additional indicator variables, each representing sectors where we expect this outperformance to be more pronounced. The first moderator is an indicator variable that takes the value of one for firms that are in business-to-consumer (B2C) sectors and zero for firms that are in business-to-business (B2B) sectors. We expect that High Sustainability firms will outperform their counterparts more in B2C businesses. In B2C businesses, individual consumers are the customers, in contrast to B2B businesses where companies and governments are the customers. The sensitivity of individual consumers to the company's public perception is higher (Corey, 1991; Du, Bhattacharya, and Sen 2007; Lev, Petrovits, and Radhakrishnan, 2010) and, as a result, the link between 
sustainability and greater customer satisfaction, loyalty, and buying decisions should be stronger in B2C businesses.

The second moderator is an indicator variable that takes the value of one for firms that are in sectors where competition is predominantly driven by brand and reputation. Competing in such industries usually requires employing high quality human capital for developing new products and sophisticated marketing campaigns, and investment in continuous and rapid innovation. In these sectors, we expect that the link between sustainability and attracting better employees, attaining higher levels of innovation, and the management of reputational risk will be stronger. We proxy for sectors where brands and reputation are relatively more important by constructing an indicator variable taking the value of one for sectors that score at the fourth quartile of the market-to-book ratio in 1993 across all companies.

Finally, the third moderator is an indicator variable that takes the value of one for sectors where firms' products significantly depend upon extracting large amounts of natural resources (e.g. oil and gas, chemicals, industrial metals, and mining). Particularly in recent years, firms in these sectors have been subject to intense public scrutiny and many times have been in conflict with their local communities. Moreover, environmental impact and resource scarcity are increasingly pressing social issues that have increased regulation and put pressure on companies to minimize their environmental impact and become more resource efficient. Therefore, we expect the link between sustainability and a more secure license to operate, better community relations, and commercial benefits from a smaller environmental impact and resource efficiency to be stronger in these sectors.

Table 8 presents the results from the cross-sectional model. In all specifications we include sector fixed effects. In the first column, the model includes as an independent variable only the indicator variable for High Sustainability firms. As expected, the coefficient is positive and significant. In the second column we introduce the interaction terms with the moderators variables. All three coefficients on the interaction terms are positive, as predicted. The coefficients on High Sustainability $x$ B2C and High Sustainability $x$ Brand are significant at the 5\% level. The coefficient on High Sustainability $x$ Natural Resources is significant at the $10 \%$ level. High Sustainability firms in B2C or Brand sectors outperform their counterparts in 13 out of 18 calendar years whereas High Sustainability firms in the Natural Resources sector outperform their counterparts in 11 out of 18 years. Overall, the results in Table 8 support our predictions that firms that integrated social and environmental issues in their business model and strategy have benefited relatively more in B2C sectors and in sectors where companies compete on the basis of brands and human capital, and where firms' products depend on extracting large amounts of natural resources.

\section{Alternative Explanations}

Alternative Explanation I: Price Pressure from SRI funds 
We conclude this section by discussing alternative explanations. One potential explanation of higher stock returns for High Sustainability firms is price pressure from the emergence of Socially Responsible Investing (SRI). According to the Social Investment Forum, institutional investors that claim to incorporate ESG data into their investment decisions had $\$ 162$ billion in assets under management in 1995 and \$2.5 trillion in 2010. However, the number of SRI funds that actually practice ESG integration in a systematic way is lower with most SRI funds practicing "negative screening" (i.e., excluding from the investment universe specific sectors, such as tobacco), an investment strategy that does not affect our results since the two groups have exactly the same industry composition. Nonetheless, to better understand whether our results are driven by price pressure, and to mitigate concerns around the inefficiency of stock prices as a performance metric, we examine the accounting performance of the two groups of firms, which should not be affected by price pressure in stock markets. Moreover, the use of accounting measures addresses concerns over stock price as a performance measure in the presence of market inefficiencies that can prevent operating performance from being reflected in stock prices.

We find that High Sustainability firms outperform traditional ones when we consider accounting rates of return. Figure 3 shows the cumulative performance of $\$ 1$ of assets based on ROA. Investing \$1 in assets in the beginning of 1993 in a value-weighted (equal-weighted) portfolio of High Sustainability firms would have grown to $\$ 7.1$ ( $\$ 3.5$ ) by the end of 2010. In contrast, investing $\$ 1$ in assets in a valueweighted (equal-weighted) portfolio of control firms would have grown to $\$ 4.4$ (\$3.3). Figure 4 shows the cumulative performance of $\$ 1$ of equity based on ROE. Investing $\$ 1$ in book value of equity in the beginning of 1993 in a value-weighted (equal-weighted) portfolio of High Sustainability firms would have grown to $\$ 31.7$ ( $\$ 15.8$ ) by the end of 2010. In contrast, investing $\$ 1$ in book value of equity in a value-weighted (equal-weighted) portfolio of control firms would have grown to $\$ 25.7(\$ 9.3) .^{8}$ The portfolio of High Sustainability firms outperforms the portfolio of control firms in 14 out of 18 years. These results suggest that the stock market outperformance is founded on a solid outperformance in accounting profitability.

\section{Alternative Explanation II: Sustainability as a Luxury Good}

Another alternative explanation is that the adoption of environmental and social policies is a luxury good that firms can afford when they are performing well and therefore including in the Low Sustainability group companies that throughout the years did not adopt these policies, is equivalent to selecting firms that will underperform. To be more specific, a bias would only arise if an unidentified characteristic is correlated with the sustainability policies, is uncorrelated with performance in the early $90 \mathrm{~s}$, and it is

\footnotetext{
${ }^{8}$ It is worth noting that a substantial number of firms in the Low Sustainability group adopted a few environmental and social policies throughout the 2000s. If this is not purely due to greenwashing, then this might bias our results against finding performance differences across the two groups.
} 
correlated with performance after 1993. However, the argument is inconsistent with the fact that in the early 1990s the two sets of firms had statistically identical performance but had adopted very different policies. It is also inconsistent with operating performance and leverage not being significant in the logit model of propensity score matching, and with the fact that Low Sustainability firms have positive alphas in the future. Moreover, when we test if past profitability is correlated with future adoption of policies (changes in Sustainability Policies) we do not find a significant positive association. The coefficient on past performance (e.g., three-year cumulative ROA, ROE, or stock returns) is slightly negative and insignificant. Finally, the luxury good argument would predict that companies would drop these policies in challenging times, such as during the financial crisis of 2008 and 2009. Contrary to this argument, we find that in fact, companies slightly increased the number of policies during the financial crisis. Sustainability Policies the equal-weighted policy index - increased from 0.28 in 2007 to 0.33 , 0.34, and 0.36 in 2008, 2009, and 2010 respectively.

\section{Alternative Explanation III: Omitted Risk Factor}

The stock market outperformance documented here might be driven by an omitted risk factor that we have been unable to identify and account for. Accordingly, we examine analyst surprises to annual earnings announcements to differentiate between the omitted risk factor explanation and the market not fully incorporating in stock prices the future profitability of High Sustainability firms. Table 9 shows the results of analyzing forecast errors for the two groups of firms. We report results using as dependent variables forecast errors (i.e. actual earnings minus the consensus forecasts) deflated by both the standard deviation of analyst forecasts (SUE) and the absolute consensus forecast (\%FE). Consistent with previous research, we use the most recent consensus forecast error before the earnings announcement (Edmans, 2011). The coefficient on High Sustainability is positive and significant, suggesting that High Sustainability firms have higher positive forecast errors and analysts being more positively surprised by the future earnings of these firms.

\section{Alternative Explanation IV: Survivorship Bias and Future Default Rates}

In our primary sample selection we identified firms that had survived until the late 2000s because we were interested in studying companies that have adopted environmental and social policies for multiple consecutive years.. Because we have imposed the survivorship criterion for both groups of firms, it should not affect the relative performance of the two groups. However, one remaining concern is that integration of social and environmental issues might be a high risk-high return strategy that leads to a higher probability of default and liquidation for a company. In untabulated results we calculate the index of Sustainability Policies for all US firms with available data in 2003. Then we calculate the probability of default and liquidation for each firm between 2004 and 2010. We do not observe any systematic relation between Sustainability Policies and probability of default. Controlling for other determinants of default 
we find that the coefficient on Sustainability Policies is negative and insignificant, suggesting that firms that have adopted more environmental and social policies have a lower probability of default, although this estimate is not reliably different than zero.

\section{Alternative Explanation V: Corporate Governance as a Correlated Omitted Variable}

Correlated omitted variables could be causing both the adoption of sustainability policies and future performance. Our matching procedure attempted to create two statistically identical groups of firms, but other characteristics that did not enter the matching algorithm could still be influencing the results. One such variable could be corporate governance. Gompers et al. (2003) show that firms with more shareholder-friendly governance provisions (G-index) outperformed their competitors in the 1990s. If High Sustainability firms have a lower G-index, then the results documented here might be driven by governance differences. However, we find that firms classified as High Sustainability have a higher Gindex (average is 9.6) compared to Low Sustainability firms (average is 8.2), suggesting that High Sustainability firms have more powerful boards and less shareholder-friendly provisions. Moreover, we analyzed the board characteristics of the two groups of firms in terms of independence and size. We did not find any differences across the two groups.

\section{Discussion}

In this article we studied a matched sample of 180 companies, 90 of which we classified as High Sustainability firms because they long ago adopted policies guiding their impact on the society and the environment, while another 90 we classified as Low Sustainability firms because they had not. The Low Sustainability firms largely correspond to the traditional model of corporate profit maximization in which social and environmental issues are predominantly regarded as externalities. Often enough, responsibility for forcing corporations to account for such externalities, whether positive or negative, rests with governments and various laws and regulations that mandate certain kind of remedial actions. The High Sustainability firms in contrast, not only pay attention to externalities but in fact, such firms are characterized by distinct governance mechanisms which directly involve the board in sustainability issues and link executive compensation to sustainability objectives; a much higher level of and deeper stakeholder engagement, coupled with mechanisms for making it as effective as possible, including reporting; a longer-term time horizon in their external communications which is matched by a larger proportion of long-term investors; greater attention to nonfinancial measures regarding employees; a greater emphasis on external environmental and social standards for selecting, monitoring and measuring the performance of their suppliers; and a higher level of transparency in their disclosure of nonfinancial information. In addition, during the 18-year period we studied, the High Sustainability firms outperformed the Low Sustainability ones in terms of both stock market and accounting measures while the market did not actually expect this outperformance. Our results also suggest that High Sustainability 
firms benefited relatively more in $\mathrm{B} 2 \mathrm{C}$ sectors and in sectors where companies compete on the basis of brands and human capital, and where firms' products depend on extracting large amounts of natural resources.

We note that as with any quasi-experiment that lacks random assignment of treatment in a laboratory setting, causality rather than correlation, between the independent variable and the dependent variables of interest is up for debate. While we believe that our research design has many appealing characteristics, we acknowledge the possibility that confounding factors might still exist. Future research can examine the robustness and generalizability of our results to other settings, such as in other countries or within the financial sector, and across different firm types, such as in private and smaller firms. Moreover, an open question is whether our results generalize to firms that have adopted environmental and social policies more recently. The difficulty in conducting such a study would be to distinguish between companies that just mechanically mimic their peers with respect to sustainability policies and those that adopt a more strategic approach.

More specifically, we suggest four areas for future research. The first area is to develop a better understanding of the conditions under which companies decide to incorporate social and environmental issues into their business model. The second area is the mechanisms by which such issues get integrated. Two firms in the same conditions favoring the integration of social and environmental issues could differ in the extent and speed with which they are able to do so. The third area for research is understanding how the results presented in this paper vary across countries. In the presence of different legal, cultural, and political institutions that affect corporate behavior with regards to sustainability (Ioannou and Serafeim, 2010), one might expect High Sustainability firms to outperform even more than we have documented here compared or to even underperform. Fourth, it would be useful to have deeper insights into how differences in internal resource allocation resulting from the different characteristics of these firms lead to the superior performance of the High Sustainability ones. For example, are these firms less likely to cut back on R\&D investments, lay off employees, and consolidate suppliers in economic down cycles?

We note that, for the most part, even on those characteristics where the High Sustainability firms were significantly different than their counterparts, the absolute percentages are relatively low. This raises another interesting and important question, which is "What is the optimal degree of adoption of sustainability policies and practices?" Since sustainability involves tradeoffs, both across financial and nonfinancial objectives, and between nonfinancial objectives themselves, such choices need to be well understood in order to inform decision-making. 


\section{References}

Aupperle, K. E., Carroll, A. B., and Hatfield, J. D. 1985. An empirical examination of the relationship between corporate social responsibility and profitability. Academy of Management Journal, 28(2): 446-463.

Balotti, R. and Hanks, J. 1999. Giving at the office: a reappraisal of charitable contributions by corporations. Business Lawyer 54 (3): 956-966.

Brochet, F., Loumioti, M., and Serafeim, G. 2012. Short-termism, Investor Clientele, and Firm Risk. Harvard Business School Working Paper.

Brown, W., Helland, E., and Smith, K. 2006. Corporate philanthropic practices. Journal of Corporate Finance 12: 855-877.

Bushee, B.J. and Noe, C. 2001. Corporate Disclosure Practices, Institutional Investors, and Stock Return Volatility. Journal of Accounting Research, 38: 171-202

Bushee, B. J. 2000. Do Institutional Investors Prefer Near-Term Earnings over Long-Run Value? Contemporary Accounting Research, 18(2): 207-246

Cheng, B., Ioannou, I. and Serafeim, G. 2011. Corporate Social Responsibility and Access to Finance. HBS Working Paper Series 11-130

Choi, J., and Wang, H., 2009. Stakeholder Relations and the Persistence of Corporate Financial Performance. Strategic Management Journal, 30: 895-907

Clotfelter, C. 1985. Federal tax policy and charitable giving. Chicago: University of Chicago Press.

Cochran, P. L. and Wood, R. A. 1984. Corporate social responsibility and financial performance. The Academy of Management Journal, 27(1): 42-56.

Du, S., Bhattacharya, C. B., and Sen, S. 2007. Reaping relational rewards from corporate social responsibility: the role of competitive positioning. International Journal of Research in Marketing 24: 224-241.

Eccles, R. G., and Krzus, M. 2010. One Report: Integrated Reporting for a Sustainable Strategy. New York: John Wiley and Sons, Inc.

Eccles, R. G., Edmondson, A. C., and Serafeim, G. 2011. A Note on Water. Harvard Business School Note 412-050.

Eccles, R., Krzus, M., and Serafeim, G. 2011 Market Interest in Nonfinancial Information. Harvard Business School Working Paper, No. 12-018. 
Edmans, A. 2011. Does the Stock Market Fully Value Intangibles? Employee Satisfaction and Equity Prices. Journal of Financial Economics, 101: 621-640.

Fama, E., and French, K. 2000. Forecasting Profitability and Earnings. Journal of Business, 73 (2): 161-175.

Foo, L.M., 2007. Stakeholder engagement in emerging economies: considering the strategic benefits of stakeholder engagement in a cross-cultural and geopolitical context. Corporate Governance, 7(4): 379-387.

Friedman, M., 1970. The social responsibility of business is to increase its profits. New York Times Magazine, 13 Sept., 32 (33): 122-126.

Freeman, R. E., 1984. Strategic Management: A stakeholder perspective. Boston, MA: Piman, United States.

Freeman, R. E., Harrison, J. S., and Wicks, A. C., 2007. Managing for stakeholders: survival, reputation, and success. New Haven, CT: Yale University Press, United States.

Freeman, R. E., Harrison, J. S., Wicks, A. C., Parmar, B. L., de Colle, S., 2010. Stakeholder theory: the state of the art. Cambridge University Press, New York, United States.

Galaskiewicz, J. 1997. An Urban Grants Economy Revisited: Corporate Charitable Contributions in the Twin Cities, 1979-81, 1987-89. Administrative Science Quarterly, 42(3): 445-471.

Greening, D. W. and Turban, D. B., 2000. Corporate Social Performance as a Competitive Advantage in Attracting a Quality Workforce. Business \& Society, 39(3): 254-280.

Godfrey, P. C. 2005. The Relationship between Corporate Philanthropy and Shareholder Wealth: A Risk Management Perspective. Academy of Management Review, 30(4): 777-798.

Gompers, P., Ishii, J., and Metrick, A. 2003. Corporate Governance and Equity Prices. Quarterly Journal of Economics 118 (1): 107-156.

Govindarajan, V., and Gupta, A. 1985. Linking Control Systems to Business Unit Strategy: Impact on Performance. Accounting, Organizations, and Society 10 (1): 51-66.

Healy, P., and Serafeim, G. 2011. Causes and Consequences of Firms' Anticorruption Efforts. Harvard Business School Working Paper.

Hill, C., and Jones, G. 2001. Strategic Management. Houghton Mifflin.

Hillman, A. J. and Keim, G. D., 2001. Shareholder Value, Stakeholder Management, and Social Issues: What's the Bottom Line? Strategic Management Journal, 22(2): 125-139. 
Ioannou, I. and Serafeim, G. 2010. What Drives Corporate Social Performance? The Role of Nation-level Institutions. HBS Working Paper Series 11-016

Ioannou, I. and Serafeim, G. 2011. The Consequences of Mandatory Corporate Sustainability Reporting. $H B S$ Working Paper Series 11-100.

Ittner, C., Larcker, D., and Rajan, M. 1997. The Choice of Performance Measures in Annual Bonus Contracts. The Accounting Review 72 (2): 231-255.

Jensen, M. and Meckling, W. 1976. Theory of the Firm: Managerial Behavior, Agency Costs and Ownership Structure. Journal of Financial Economics 3(4): 305-360.

Jensen, M. 2001. Value Maximization, Stakeholder Theory and the Corporate Objective Function. Journal of Applied Corporate Finance (fall): 8-21.

Jenter, D., Lewellen, K. and Warner, J.B. 2011.Security Issue Timing: What Do Managers Know, and When Do They Know It? The Journal of Finance, 66(2):413-443.

Kaplan, R., and Norton, D. 1996. Using the Balanced Scorecard as a Strategic Management System. Harvard Business Review 74, no. 1 (January-February ): 75-85.

Kaplan, R., and Norton D. 2008. Execution Premium: Linking Strategy to Operations for Competitive Advantage. Harvard Business School Press.

Lev, B., Petrovits, C., and Radhakrishnan, S. Is doing good good for you? How corporate charitable contributions enhance revenue growth. Strategic Management Journal 31: 182-200.

Jones, T.M., 1995. Instrumental stakeholder theory: A Synthesis of Ethics and Economics. Academy of Management Review, 20: 404-437.

Laverty, K. J. 1996. Economic "Short-Termism": The Debate, The Unresolved Issues, and The Implications for Management Practice and Research. The Academy of Management Review, 21(3) 825-860.

Margolis, J. D. and Walsh, J. P. 2003. Misery loves companies: Rethinking social initiatives by business. Administrative Science Quarterly, 48(2): 268-305.

Marquis, C., and Toffel, M. 2011. The Globalization of Corporate Environmental Disclosure: Accountability or Greenwashing? Harvard Business School Working Paper, No. 11-115. 
Margolis, J. D., Elfenbein, H. A., and Walsh, J. P. 2007. Does It Pay To Be Good? A Meta-Analysis and Redirection of Research on the Relationship Between Corporate Social and Financial Performance, Working paper.

McWilliams, A. and Siegel, D. 2001. Corporate social responsibility: A theory of the firm perspective. Academy of Management Review, 26(1): 117-127.

Navarro, P. 1988. Why do corporations give to charity? Journal of Business, 61(1): 65-93.

Paine, Lynn Sharp. Value Shift: Why Companies Must Merge Social and Financial Imperatives to Achieve Superior Performance. New York: McGraw-Hill, 2004.

Porter, M., and Kramer, M. 2011. Creating Shared Value. Harvard Business Review, 89 (1/2): 62-77.

Poterba, J.M. and Summers, L.H. 1988. Mean Reversion in Stock Prices: Evidence and Implications. Journal of Financial Economics, 22(1): 27-59.

Sen, S., Gurhan-Canli, Z. And Morwitz, V. 2001. Withholding Consumption: A Social Dilemma Perspective on Consumer Boycotts. Journal of Consumer Research, 28(3): 399-417.

Simnett, R., A. Vantraelen, and W. F. Chua. 2009. Assurance on Sustainability Reports: An International Comparison. The Accounting Review 84 (May): 937-967.

Stein, J. 1989. Efficient Capital Markets, Inefficient Firms: A Model of Myopic Corporate Behavior Quarterly Journal of Economics 104: 655-669.

Ullmann, A. A. 1985. Data in search of a theory: a critical examination of the relationships among social performance, social disclosure, and economic performance of US firms. Academy of Management Review, 10(3): 540-557.

Waddock, S. A. and Graves, S. B. 1997. The corporate social performance-financial performance link. Strategic Management Journal, 18(4): 303-319.

Wood, D. J. and Jones, R. E. 1995. Stakeholder mismatching: A theoretical problem in empirical research on corporate social performance. International Journal of Organizational Analysis, 3: 229-267.

Zingales, L. 2000. In Search of New Foundations. The Journal of Finance, 55(4): 1623-1653. 


\section{Table 1 Summary statistics for two groups}

Panel A: Sector composition of the sample

\begin{tabular}{lc}
\hline Sector & \% of sample \\
\hline Oil \& Gas Producers & $4.4 \%$ \\
Oil Equipment, Services \& Distribution & $3.3 \%$ \\
Chemicals & $5.6 \%$ \\
Industrial Metals & $1.1 \%$ \\
Mining & $1.1 \%$ \\
Construction \& Materials & $1.1 \%$ \\
Aerospace \& Defense & $1.1 \%$ \\
General Industrials & $4.4 \%$ \\
Electronic \& Electrical Equipment & $2.2 \%$ \\
Industrial Engineering & $3.3 \%$ \\
Industrial Transportation & $1.1 \%$ \\
Support Services & $1.1 \%$ \\
Automobiles \& Parts & $3.3 \%$ \\
Beverages & $1.1 \%$ \\
Food Producers & $4.4 \%$ \\
Household Goods \& Home Construction & $3.3 \%$ \\
Leisure Goods & $3.3 \%$ \\
Personal Goods & $2.2 \%$ \\
Health Care Equipment \& Services & $7.8 \%$ \\
Pharmaceuticals \& Biotechnology & $4.4 \%$ \\
Retailers & $5.6 \%$ \\
Media & $3.3 \%$ \\
Travel \& Leisure & $3.3 \%$ \\
Fixed Line Telecommunications & $2.2 \%$ \\
Mobile Telecommunications & $1.1 \%$ \\
Electricity & $6.7 \%$ \\
Gas, Water \& Multi-utilities & $3.3 \%$ \\
Software \& Computer Services & $5.6 \%$ \\
Technology Hardware \& Equipment & $8.9 \%$ \\
\hline Total & $100.0 \%$ \\
\hline
\end{tabular}


Panel B: Firm characteristics across two groups at the year of matching (1993)

\begin{tabular}{|c|c|c|c|c|c|c|c|c|c|c|c|c|c|}
\hline & & Tota & ssets & ROA & & ROE & & Leverage & & Turnover & & MTB & \\
\hline $\begin{array}{l}\text { Sustainability } \\
\text { Low }\end{array}$ & $\begin{array}{l}\mathrm{N} \\
90\end{array}$ & $\begin{array}{c}\text { Average } \\
8,182\end{array}$ & $\begin{array}{c}\text { St. Dev. } \\
28,213\end{array}$ & $\begin{array}{c}\text { Average } \\
7.54\end{array}$ & $\begin{array}{c}\text { St. Dev. } \\
8.02\end{array}$ & $\begin{array}{c}\text { Average } \\
10.89\end{array}$ & $\begin{array}{c}\text { St. Dev. } \\
20.61\end{array}$ & $\begin{array}{c}\text { Average } \\
0.57\end{array}$ & $\begin{array}{c}\text { St. Dev. } \\
0.19\end{array}$ & $\begin{array}{c}\text { Average } \\
1.05\end{array}$ & $\begin{array}{c}\text { St. Dev. } \\
0.62\end{array}$ & $\begin{array}{c}\text { Average } \\
3.41\end{array}$ & $\begin{array}{c}\text { St. Dev. } \\
2.18\end{array}$ \\
\hline High & 90 & 8,591 & 22,230 & 7.86 & 7.54 & 11.17 & 16.15 & 0.56 & 0.18 & 1.02 & 0.57 & 3.44 & 1.88 \\
\hline p-value diff & & 0.914 & & 0.781 & & 0.919 & & 0.726 & & 0.703 & & 0.927 & \\
\hline
\end{tabular}

Panel A: Frequency tabulation of sector membership for the 180 firms in the sample.

Panel B: All measures are calculated at the end of fiscal year in 1993. Averages and standard deviations across the High Sustainability and the Low Sustainability group are presented. Each group includes 90 firms. ROA is net income plus net interest expense after tax over total assets. ROE is net income over shareholder's equity. Leverage is total liabilities over total assets. Turnover is sales over assets. MTB is stock price over book value of equity per share. p-value is derived from a test of the equality of the means across the two groups. 
Table 2

Governance

Panel A: Frequency Analysis of Governance

\begin{tabular}{lccc}
\hline & \multicolumn{2}{c}{ Sustainability } & Difference \\
\hline Governance & Low & High & p-value \\
\hline Board & & & \\
Formal Board Responsibility / Corporate Citizenship & $21.6 \%$ & $52.7 \%$ & $<0.001$ \\
Sustainability committee & $14.7 \%$ & $40.9 \%$ & $<0.001$ \\
Compensation & & & \\
Variable Compensation Metrics / Social Metrics & $21.6 \%$ & $35.1 \%$ & 0.022 \\
Variable Compensation Metrics / Environmental Metrics & $8.1 \%$ & $17.6 \%$ & 0.011 \\
Variable Compensation Metrics / External Perception Metrics & $10.8 \%$ & $32.4 \%$ & 0.004 \\
\hline
\end{tabular}

This panel reports the frequency of stakeholder engagement practices across the two groups, low and high sustainability. p-value is derived from a test of the equality of the frequencies across the two groups. "Formal Board Responsibility / Sustainability" is the percentage of companies that the board of directors explicitly assumes formal responsibility over corporate social responsibility or sustainability. "Sustainability committee" is the percentage of companies with a separate sustainability board committee. "Variable Compensation Metrics / Social Metrics" is the percentage of companies with pre-defined corporate social indicators (e.g. corporate Health \& Safety figure) relevant for the variable compensation of Executive / Top Management. "Variable Compensation Metrics / Environmental Metrics" is the percentage of companies with pre-defined corporate environmental indicators (e.g. corporate Emission reduction) relevant for the variable compensation of Executive / Top Management. "Variable Compensation Metrics / External Perception Metrics" is the percentage of companies with pre-defined corporate external perception indicators (e.g. reputational risks, customer satisfaction, feedback from stakeholder engagement) relevant for the variable compensation of Executive / Top Management.

\section{Panel B: Multivariate Analysis of Governance}

\begin{tabular}{lrr}
\hline Parameter & Estimate & p-value \\
\hline Intercept & -0.773 & 0.003 \\
High Sustainability & 0.144 & 0.006 \\
Size & 0.084 & 0.002 \\
MTB & -0.006 & 0.563 \\
ROA & 0.011 & 0.055 \\
Sector f.e. & Yes & \\
N & 180 & \\
Adj R-squared & $37.9 \%$ & \\
\hline
\end{tabular}

This panel reports coefficient estimates and the statistical significance of these coefficients from an OLS model where the dependent variable is the percentage of governance mechanisms in Panel A that a firm has adopted. "High Sustainability" is an indicator variable that takes the value of one if a firm is included in the High Sustainability group. "Size" is the natural logarithm of market capitalization at the end of 2009. "MTB" is stock price over book value of equity per share at the end of 2009 . "ROA" is net income plus net interest expense after tax over total assets at the end of 2009. Standard errors are robust to heteroscedasticity. 
Table 3

Stakeholder Engagement

Panel A: Frequency Analysis of Stakeholder Engagement

\begin{tabular}{lccc}
\hline & \multicolumn{2}{c}{ Sustainability } & Difference \\
\hline Stakeholder Engagement & Low & High & p-value \\
\hline Prior & & & \\
Opportunities Risks Examination & $2.7 \%$ & $31.1 \%$ & $<0.001$ \\
Stakeholder Identification & $10.8 \%$ & $45.9 \%$ & $<0.001$ \\
Training & $0.0 \%$ & $14.9 \%$ & $<0.001$ \\
During & & & \\
Concerns & $2.7 \%$ & $32.4 \%$ & $<0.001$ \\
Grievance Mechanism & $2.7 \%$ & $18.9 \%$ & $<0.001$ \\
Common Understanding & $13.5 \%$ & $36.5 \%$ & $<0.001$ \\
Scope Agreement & $8.1 \%$ & $36.5 \%$ & $<0.001$ \\
Targets & $0.0 \%$ & $16.2 \%$ & $<0.001$ \\
After & & & \\
Board Feedback & $5.4 \%$ & $32.4 \%$ & $<0.001$ \\
Result Reporting & $0.0 \%$ & $31.1 \%$ & $<0.001$ \\
Public Reports & $0.0 \%$ & $20.3 \%$ & $<0.001$ \\
\hline
\end{tabular}

This panel reports the frequency of stakeholder engagement practices across the two groups, low and high sustainability. p-value is derived from a test of the equality of the frequencies across the two groups. "Opportunities Risks Examination" is the percentage of companies that undertake an examination of costs, opportunities and risks prior to a particular stakeholder engagement. "Stakeholder Identification" is the percentage of companies that identify issues and stakeholders that appear to be most important for long-term success. "Training" is the percentage of companies with local managers getting training in stakeholder engagement. "Concerns" is the percentage of companies for which the process of engagement ensures that all stakeholders can rise their concerns. "Grievance Mechanism" is the percentage of companies where grievance mechanisms are agreed upon by all involved parties. "Common Understanding" is the percentage of companies which formally pursue a development of a common understanding of issues relevant to the underlying problem, such as technical terms. "Scope Agreement" is the percentage of companies that pursue mutual agreement on the type of engagement (type of meetings such as group meetings, one-on-ones, frequency of meetings, exchange of information, roles of each party etc.) "Targets" is the percentage of companies with stakeholder engagement that targets are set and agreed upon by all involved parties. "Board Feedback" is the percentage of companies for which feedback from stakeholders is provided to board/supervisory board and/or senior directors and/or compliance and/or communication department. "Result Reporting" is the percentage of companies with results of the engagement process being reported to the stakeholders involved. "Public Reports" is the percentage of companies that make the results of the engagement process publicly available. 


\section{Panel B: Multivariate Analysis of Stakeholder Engagement}

\begin{tabular}{lrr}
\hline Parameter & Estimate & \multicolumn{1}{c}{ p-value } \\
\hline Intercept & -0.428 & 0.167 \\
High Sustainability & 0.245 & $<.0001$ \\
Size & 0.073 & 0.013 \\
MTB & -0.011 & 0.255 \\
ROA & 0.003 & 0.661 \\
Sector f.e. & Yes & \\
N & 180 & \\
Adj R-squared & $37.9 \%$ & \\
\hline
\end{tabular}

This panel reports coefficient estimates and the statistical significance of these coefficients from an OLS model where the dependent variable is the percentage of stakeholder engagement mechanisms in Panel A that a firm has adopted. "High Sustainability" is an indicator variable that takes the value of one if a firm is included in the High Sustainability group. "Size" is the natural logarithm of market capitalization at the end of 2009. "MTB" is stock price over book value of equity per share at the end of 2009. "ROA" is net income plus net interest expense after tax over total assets at the end of 2009. Standard errors are robust to heteroscedasticity. 
Table 4

\section{Long-term Orientation}

Panel A: Univariate Analysis of Long-term Orientation

\begin{tabular}{lccc}
\hline & \multicolumn{2}{c}{ Sustainability } & Difference \\
\hline Measures of long-term orientation & Low & High & p-value \\
\hline Long-term vs. Short-term Investors & -5.31 & -2.29 & $<0.001$ \\
Long-term vs. Short-term Discussion & 0.96 & 1.08 & 0.030 \\
\hline
\end{tabular}

This table reports the average long-term orientation of the two groups, low and high sustainability. p-value is derived from a test of the equality of the means across the two groups. "Long-term vs. Short-term Investors" is the percentage of shares outstanding held by dedicated investors minus the percentage of shares held by transient investors. This investor classification is based on the one used in Bushee (2001) and Bushee and Noe (2000). "Long-term vs. Short-term Discussion" is the ratio of long-term over short-term keywords included in transcripts of discussions between the management and sell-side analysts in conference calls.

Panel B: Multivariate Analysis of Long-term Orientation

\begin{tabular}{lrrrr}
\hline Dependent variable & \multicolumn{2}{c}{$\begin{array}{c}\text { Long-term vs. Short- } \\
\text { term Investors }\end{array}$} & \multicolumn{2}{c}{$\begin{array}{c}\text { Long-term vs. Short- } \\
\text { term Discussion }\end{array}$} \\
\hline Parameter & Estimate & p-value & Estimate & p-value \\
\hline Intercept & -39.348 & $<.0001$ & 1.897 & 0.000 \\
High Sustainability & 3.012 & 0.004 & 0.038 & 0.070 \\
Size & 2.158 & $<.0001$ & -0.053 & 0.093 \\
MTB & 0.014 & 0.810 & 0.004 & 0.017 \\
ROA & 2.277 & 0.740 & -0.018 & 0.971 \\
Sector f.e. & Yes & & Yes & \\
Year f.e. & Yes & \multicolumn{4}{c}{ Yes } \\
N & 830 & & 980 & \\
Adj R-squared & $8.8 \%$ & & & \\
\end{tabular}

This panel reports coefficient estimates and the statistical significance of these coefficients from an OLS model where the dependent variable is Long-term vs. Short-term Investors or Long-term vs. Short-term Discussion in Panel A. "High Sustainability" is an indicator variable that takes the value of one if a firm is included in the High Sustainability group. "Size" is the natural logarithm of market capitalization at fiscal year-end. "MTB" is stock price over book value of equity per share at fiscal year-end. "ROA" is net income plus net interest expense after tax over total assets at fiscal year-end. The data cover years 20022008. Standard errors are robust to heteroscedasticity and clustered at the firm level. 
Table 5

\section{Measurement of Nonfinancial Information}

\section{Panel A: Employees}

\begin{tabular}{lccc}
\hline & \multicolumn{2}{c}{ Sustainability } & Difference \\
\hline Employees & Low & High & p-value \\
\hline HR Performance Indicators / Nonfinancial & $16.2 \%$ & $54.1 \%$ & $<0.001$ \\
KPI Labor / EHS Fatalities Tracking & $26.3 \%$ & $77.4 \%$ & $<0.001$ \\
KPI Labor / EHS Near Miss Tracking & $26.3 \%$ & $64.5 \%$ & $<0.001$ \\
KPI Labor / EHS Performance Tracking & $89.5 \%$ & $95.2 \%$ & 0.871 \\
\hline
\end{tabular}

This table reports the frequency of stakeholder engagement practices across the two groups, low and high sustainability. p-value is derived from a test of the equality of the frequencies across the two groups. "HR Performance Indicators/Nonfinancial" is the percentage of companies that use HR Performance Indicators / Nonfinancial (e.g. number of hours spent in trainings, companyspecific skills categorization) to measure execution of skill mapping and development strategy. "KPI Labor/EHS Fatalities Tracking" is the percentage of companies that use fatalities tracking to follow labor relations issues. "KPI Labor/EHS Near Miss Tracking" is the percentage of companies that use near miss tracking to follow labor relations issues. "KPI Labor/EHS Performance Tracking" is the percentage of companies that use health and safety performance tracking to follow labor relations issues.

\section{Panel B: Customers}

\begin{tabular}{lccc}
\hline & \multicolumn{2}{c}{ Sustainability } & Difference \\
\hline Customers & Low & High & p-value \\
\hline Customer Lifestyle & $2.7 \%$ & $5.4 \%$ & 0.461 \\
Geographical Segmentation & $10.8 \%$ & $18.9 \%$ & 0.101 \\
Potential Lifetime Value & $2.7 \%$ & $8.1 \%$ & 0.164 \\
Customer Generated Revenues & $8.1 \%$ & $18.9 \%$ & 0.041 \\
Historical Sales Trends & $8.1 \%$ & $16.2 \%$ & 0.100 \\
Products Bought & $8.1 \%$ & $14.9 \%$ & 0.194 \\
Cost Of Service & $2.7 \%$ & $6.8 \%$ & 0.279 \\
\hline
\end{tabular}

This table reports the frequency of stakeholder engagement practices across the two groups, low and high sustainability. p-value is derived from a test of the equality of the frequencies across the two groups. "Customer Lifestyle" is the percentage of companies that use customer lifestyle to segment customers in the company's CRM database. "Geographic Segmentation" is the percentage of companies that use geographic segmentation to segment customers in the company's CRM database. "Potential Lifetime Value" is the percentage of companies that use the potential lifetime value to business to segment customers in the company's CRM database. "Customer Generated Revenues" is the percentage of companies that use the revenues generated by customers to segment customers in the company's CRM database. "Historical Sales Trends" is the percentage of companies that use historical sales trends to segment customers in the company's CRM database. "Products Bought" is the percentage of companies that use products/services bought to segment customers in the company's CRM database. "Cost of Service" is the percentage of companies that use the costs of services to segment customers in the company's CRM database. 


\section{Panel C: Suppliers}

\begin{tabular}{lccc}
\hline & \multicolumn{2}{c}{ Sustainability } & Difference \\
\hline Suppliers & Low & High & p-value \\
\hline Environmental & & & \\
EMS & $18.2 \%$ & $50.0 \%$ & $<0.001$ \\
Environmental Production Standards & $25.7 \%$ & $45.6 \%$ & $<0.001$ \\
Environmental Data Availability & $0.0 \%$ & $12.3 \%$ & 0.018 \\
Environmental Policy & $0.0 \%$ & $17.4 \%$ & $<0.001$ \\
Product LCA & $0.0 \%$ & $6.6 \%$ & 0.052 \\
Social & & & \\
Human Right Standards & $5.7 \%$ & $17.4 \%$ & $<0.001$ \\
OHS Standards & $25.7 \%$ & $62.9 \%$ & $<0.001$ \\
Grievance Process & $0.0 \%$ & $8.1 \%$ & 0.039 \\
Labor Standards & $8.1 \%$ & $18.6 \%$ & 0.020 \\
Standards & & & \\
International Standards Compliance & $0.0 \%$ & $12.3 \%$ & $<0.001$ \\
National Standards Compliance & $8.1 \%$ & $14.9 \%$ & 0.057 \\
\hline
\end{tabular}

This table reports the frequency of stakeholder engagement practices across the two groups, low and high sustainability. p-value is derived from a test of the equality of the frequencies across the two groups. "EMS" is the percentage of companies that use EMS in their certification/audit/verification process. "Environmental Production Standards" is the percentage of companies that use environmental production standards to select and evaluate the company's key suppliers and services providers. "Environmental Data Availability" is the percentage of companies that use environmental data availability to select and evaluate the company's key suppliers and services providers. "Environmental Policy" is the percentage of companies that use environmental policy to select and evaluate the company's key suppliers and services providers. "Product LCA" is the percentage of companies that use product lifecycle impact assessment to select and evaluate the company's key suppliers and services providers. "Human Rights Standards" is the percentage of companies that use human rights standards (such as forced, slave labor, child labor) to select and evaluate the company's key suppliers and services providers. "OHS Standards" is the percentage of companies that use occupational health \& safety to select and evaluate the company's key suppliers and services providers. "Grievance Process" is the percentage of companies that use grievance process implementation to select and evaluate the company's key suppliers and services providers. "Labor Standards" is the percentage of companies that use labor standards/requirements to select and evaluate the company's key suppliers and services providers. "International Standards Compliance" is the percentage of companies that use international standards compliance to select and evaluate the company's key suppliers and services providers. "National Standards Compliance" is the percentage of companies that use national standards compliance to select and evaluate the company's key suppliers and services providers. 


\section{Panel D: Assurance}

\begin{tabular}{lccc}
\hline & \multicolumn{2}{c}{ Sustainability } & Difference \\
\hline Assurance & Low & High & p-value \\
\hline Sustainability report external audit & $1.4 \%$ & $11.1 \%$ & 0.017 \\
Assurance Provision Process & & & \\
Information Collection Review & $5.4 \%$ & $14.9 \%$ & 0.058 \\
Data Aggregation Review & $5.4 \%$ & $14.9 \%$ & 0.058 \\
Document Review & $5.4 \%$ & $14.9 \%$ & 0.058 \\
Relevant Management Interviews & $5.4 \%$ & $12.2 \%$ & 0.089 \\
Mapping against Standards & $2.7 \%$ & $16.2 \%$ & 0.031 \\
Auditor Competency Disclosure & $2.7 \%$ & $5.4 \%$ & 0.589 \\
Relevant Management Discussions & $5.4 \%$ & $14.9 \%$ & 0.058 \\
Sample Site Visits & $2.7 \%$ & $12.2 \%$ & 0.058 \\
Stakeholder Consultation & $0.0 \%$ & $5.4 \%$ & 0.131 \\
Distribution Network Quality & & & \\
External Audits & $8.1 \%$ & $12.2 \%$ & 0.221 \\
Standardized External Audits & $5.4 \%$ & $12.2 \%$ & 0.058 \\
Internal Audits & $5.4 \%$ & $13.5 \%$ & 0.046 \\
\hline
\end{tabular}

This table reports the frequency of stakeholder engagement practices across the two groups, low and high sustainability. p-value is derived from a test of the equality of the frequencies across the two groups. "Sustainability report external audit" is the percentage of companies with a public sustainability report that is assured by a third party. "Information Collection Review" is the percentage of companies that use a review of internal processes of information generation and collection as an element in the company's assurance provision process. "Data Aggregation Review" is the percentage of companies that use a review of data aggregation processes as an element in the company's assurance provision process. "Document Review" is the percentage of companies that use a review of documents as an element in the company's assurance provision process. "Relevant Management Interviews" is the percentage of companies that conduct interviews with management responsible for the information gather process at the corporate level as an element in the company's assurance provision process. "Mapping Against Standards" is the percentage of companies that map against relevant external standards and programs, including AA1000 and the Global Reporting Initiative, as an element in the company's assurance provision process. "Auditor Competency Disclosure" is the percentage of companies that use disclosure of competencies of assurance providers as an element in the company's assurance provision process. "Relevant Management Discussions" is the percentage of companies that incorporate relevant management discussions as an element in the company's assurance provision process. "Sample Site Visits" is the percentage of companies that conduct use sample site visits as an element in the company's assurance provision process. "Stakeholder Consultation" is the percentage of companies that consultations with stakeholders as an element in the company's assurance provision process. "External Audits" is the percentage of companies that use external audits as an element in the company's assurance provision process. "Internal Audits" is the percentage of companies that use internal audits as an element in the company's assurance provision process. 
Panel E: Multivariate Analysis of Nonfinancial Measurement

\begin{tabular}{|c|c|c|c|c|c|c|c|c|}
\hline \multirow[b]{2}{*}{ Parameter } & \multicolumn{2}{|c|}{ Employees } & \multicolumn{2}{|c|}{ Customers } & \multicolumn{2}{|c|}{ Suppliers } & \multicolumn{2}{|c|}{ Assurance } \\
\hline & Estimate & p-value & Estimate & p-value & Estimate & p-value & Estimate & p-value \\
\hline Intercept & -0.206 & 0.394 & 0.222 & 0.154 & -0.266 & 0.060 & 0.272 & 0.329 \\
\hline High Sustainability & 0.174 & 0.000 & 0.013 & 0.681 & 0.089 & 0.001 & 0.115 & 0.020 \\
\hline Size & 0.045 & 0.040 & 0.014 & 0.388 & 0.041 & 0.002 & 0.035 & 0.122 \\
\hline MTB & 0.008 & 0.331 & 0.002 & 0.843 & 0.007 & 0.176 & -0.001 & 0.887 \\
\hline ROA & -0.005 & 0.257 & -0.008 & 0.046 & -0.003 & 0.343 & -0.016 & 0.007 \\
\hline Sector f.e. & Yes & & Yes & & Yes & & Yes & \\
\hline $\mathrm{N}$ & 180 & & 180 & & 180 & & 180 & \\
\hline Adj R-squared & $30.3 \%$ & & $41.9 \%$ & & $45.1 \%$ & & $49.0 \%$ & \\
\hline
\end{tabular}

This panel reports coefficient estimates and the statistical significance of these coefficients from an OLS model where the dependent variable is the percentage of employee, customer, supplier, and assurance procedure in Panels A-D that each firm adopted. "High Sustainability" is an indicator variable that takes the value of one if a firm is included in the High Sustainability group. "Size" is the natural logarithm of market capitalization at the end of 2009. "MTB" is stock price over book value of equity per share at the end of 2009. "ROA" is net income plus net interest expense after tax over total assets at the end of 2009. Standard errors are robust to heteroscedasticity. 
Table 6

\section{Disclosure of Nonfinancial Information}

\section{Panel A: Univariate Analysis of Nonfinancial Disclosure}

\begin{tabular}{lccc}
\hline \multicolumn{2}{c}{ Sustainability } & Difference & \\
\cline { 1 - 3 } Nonfinancial disclosure & Low & High & p-value \\
\hline Quantity & & & \\
ESG Disclosure - Bloomberg & 17.86 & 29.90 & $<0.001$ \\
ESG Disclosure - Thomson Reuters & 36.91 & 46.38 & $<0.001$ \\
Coverage & & & \\
Sustainability report covers global activities & $8.3 \%$ & $41.4 \%$ & $<0.001$ \\
Integration & & & \\
Nonfinancial vs. Financial Discussion & 0.68 & 0.96 & $<0.001$ \\
Social Data Integrated in Financial Reports & $5.4 \%$ & $25.7 \%$ & 0.008 \\
Environmental Data Integrated in Financial Reports & $10.8 \%$ & $32.4 \%$ & 0.011 \\
\hline
\end{tabular}

"ESG Disclosure - Bloomberg" is the average disclosure score across the two groups, low and high sustainability. Bloomberg calculates this score based on the percentage of sustainability datapoints each company discloses. The measure ranges from 0 to 100. "ESG Disclosure - Thomson Reuters" is the average disclosure score across the two groups, low and high sustainability. We calculated this score based on the percentage of sustainability datapoints each company discloses, using Thomson Reuters ASSET4 data. The measure ranges from 0 to 100. "Sustainability report covers global activities" is the percentage of companies in each group that publishes a sustainability report that covers the global operations of the firm. "Nonfinancial vs. Financial Discussion" is the ratio of nonfinancial over financial keywords included in transcripts of discussions between the management and sell-side analysts in conference calls. The higher this number the more emphasis on nonfinancial topics a management places. "Social Data Integrated in Financial Reports" is the percentage of companies in each group that integrated social KPIs and narrative information in their financial reporting. "Environmental Data Integrated in Financial Reports" is the percentage of companies in each group that integrated environmental KPIs and narrative information in their financial reporting. 
Panel B: Multivariate Analysis of Nonfinancial Disclosure

\begin{tabular}{|c|c|c|c|c|c|c|c|c|c|c|c|c|}
\hline \multirow{2}{*}{$\begin{array}{l}\begin{array}{l}\text { Dependent } \\
\text { variable }\end{array} \\
\text { Parameter }\end{array}$} & \multicolumn{2}{|c|}{$\begin{array}{l}\text { ESG Disclosure - } \\
\text { Bloomberg }\end{array}$} & \multicolumn{2}{|c|}{$\begin{array}{l}\text { ESG Disclosure - } \\
\text { Thomson Reuters }\end{array}$} & \multicolumn{2}{|c|}{$\begin{array}{l}\text { Nonfinancial } \\
\text { vs. Financial } \\
\text { Discussion }\end{array}$} & \multicolumn{2}{|c|}{$\begin{array}{l}\text { Sustainability report } \\
\text { covers global activities }\end{array}$} & \multicolumn{2}{|c|}{$\begin{array}{l}\text { Social Data Integrated } \\
\text { in Financial Reports }\end{array}$} & \multicolumn{2}{|c|}{$\begin{array}{c}\text { Environmental Data } \\
\text { Integrated in Financial } \\
\text { Reports }\end{array}$} \\
\hline & Estimate & p-value & Estimate & p-value & Estimate & p-value & Odds ratio & p-value & Odds ratio & p-value & Odds ratio & p-value \\
\hline Intercept & -49.201 & $<.0001$ & -38.002 & $<.0001$ & -2.864 & $<.0001$ & & & & & & \\
\hline High Sustainability & 8.618 & $<.0001$ & 9.759 & $<.0001$ & 0.180 & 0.043 & 4.279 & $<0.001$ & 5.395 & 0.031 & 4.143 & 0.028 \\
\hline Size & 4.502 & $<.0001$ & 2.236 & $<.0001$ & 0.231 & $<.0001$ & 2.158 & $<0.001$ & 1.325 & 0.238 & 1.270 & 0.275 \\
\hline MTB & 0.222 & 0.095 & 0.238 & 0.095 & 0.000 & 0.841 & 0.972 & 0.069 & 1.030 & 0.744 & 1.160 & 0.070 \\
\hline ROA & -45.407 & $<.0001$ & -12.070 & $<.0001$ & -0.597 & 0.243 & 0.004 & $<0.001$ & 1.014 & 0.722 & 0.969 & 0.461 \\
\hline Sector f.e. & Yes & & Yes & & Yes & & Yes & & Yes & & Yes & \\
\hline Year f.e. & Yes & & Yes & & Yes & & Yes & & No & & No & \\
\hline $\mathrm{N}$ & 464 & & 1314 & & 980 & & 2072 & & 180 & & 180 & \\
\hline Adj R-squared & $32.1 \%$ & & $30.8 \%$ & & $11.0 \%$ & & $22.9 \%$ & & $13.2 \%$ & & $12.5 \%$ & \\
\hline
\end{tabular}

This panel reports coefficient estimates and the statistical significance of these coefficients from OLS and logistic models where the dependent variable is one of the variables reported in Panel A. Data for years 2005-2010 are used for the "ESG Disclosure - Bloomberg" analysis. Data for years 2002-2010 are used for the "ESG Disclosure - Thomson Reuters" and "Sustainability report covers global activities" analyses. Data for years 2002-2008 are used for the "Nonfinancial vs. Financial Discussion" analysis. For the last two analyses data from year 2009 are used. "High Sustainability" is an indicator variable that takes the value of one if a firm is included in the High Sustainability group. "Size" is the natural logarithm of market capitalization at the end of 2009. "MTB" is stock price over book value of equity per share at the end of 2009. "ROA" is net income plus net interest expense after tax over total assets at the end of 2009. Standard errors are robust to heteroscedasticity and clustered at the firm level (first four columns). 
Table 7

\section{Stock Market Performance}

\begin{tabular}{lcccccccc}
\hline & \multicolumn{3}{c}{ Value-weighted } & \multicolumn{3}{c}{ Equal-weighted } \\
\hline \multicolumn{3}{c}{} & \multicolumn{3}{c}{ Low } & \multicolumn{2}{c}{ High } & \multicolumn{3}{c}{ Low } & \multicolumn{2}{c}{ High } \\
\hline Parameter & Estimate & p-value & Estimate & p-value & Estimate & p-value & Estimate & p-value \\
\hline Intercept & 0.0059 & $<.0001$ & 0.0096 & $<.0001$ & 0.0039 & 0.004 & 0.0057 & $<.0001$ \\
MKTRF & 0.9839 & $<.0001$ & 0.9360 & $<.0001$ & 0.9977 & $<.0001$ & 0.9557 & $<.0001$ \\
SMB & -0.2076 & $<.0001$ & -0.1776 & 0.002 & 0.1598 & 0.001 & 0.0366 & 0.367 \\
HML & 0.1982 & 0.001 & -0.2727 & $<.0001$ & 0.4053 & $<.0001$ & 0.2204 & $<.0001$ \\
UMD & -0.0156 & 0.642 & -0.0266 & 0.427 & -0.1436 & $<.0001$ & -0.1239 & $<.0001$ \\
N & 216 & 216 & 216 & 216 & 216 & 216 & 216 & 216 \\
Adj R-squared & $85.6 \%$ & & $86.6 \%$ & & $88.9 \%$ & & $91.0 \%$ & \\
\hline
\end{tabular}

This table provides the estimates from a Fama-French four-factor model augmented by the Carhart momentum factor. The dependent variable is the monthly portfolio stock return for low or high sustainability minus the risk-free rate for that month. MKTRF is the value-weighted market return minus the risk-free rate for that month. SMB is the monthly return on a hedge portfolio that mimics the stock returns of small minus large firms. HML is the monthly return on a hedge portfolio that mimics the stock returns of low MTB minus high MTB firms. UMD is the monthly return on a hedge portfolio that mimics the stock returns of high prior returns minus low prior returns firms. The intercept represents the abnormal stock return for the average month. We estimate the model for the period 1993-2010. 


\section{Table 8}

\section{Stock Market Performance and Sector Membership}

\begin{tabular}{lrrrr}
\hline \multicolumn{1}{c}{ Parameter } & Estimate & $\mathrm{p}$-value & \multicolumn{1}{c}{ Estimate } & \multicolumn{1}{c}{$\mathrm{p}$-value } \\
\hline Intercept & 0.0118 & $<.0001$ & 0.0124 & $<.0001$ \\
High Sustainability & 0.0019 & 0.014 & -0.0008 & 0.584 \\
High Sustainability x B2C & & & 0.0040 & 0.031 \\
High Sustainability x Brand & & & 0.0038 & 0.044 \\
High Sustainability x Natural Resources & & & 0.0018 & 0.100 \\
Sector fixed effects & Yes & & Yes & \\
Adj R-squared & $32.5 \%$ & & & \\
$\mathrm{~N}$ & 180 & & & \\
\hline
\end{tabular}

This table presents estimates from OLS models where the dependent variable is the alpha for each firm from a Fama-French four-factor model augmented by the Carhart momentum factor. "High Sustainability" is an indicator variable that takes the value of one if a firm is included in the High Sustainability group. "B2C" is an indicator variable that takes the value of one for firms that operate in sectors where the customers are individual people instead of companies or governments. "Brand" is an indicator variable that takes the value of one for firms that operate in sectors that rank at the fourth quartile of market-to-book ratios in 1993. "Natural resources" is an indicator variable that takes the value of one for firms that operate in sectors that require the extraction of large amounts of natural resources. Standard errors are robust to heteroscedasticity. 


\section{Table 9}

\section{Forecast Errors}

\begin{tabular}{lrrrr}
\hline & \multicolumn{2}{c}{ SUE } & \multicolumn{2}{c}{$\%$ FE } \\
\hline Parameter & Estimate & p-value & Estimate & p-value \\
\hline Intercept & 0.860 & 0.008 & 0.082 & 0.000 \\
High Sustainability & 0.245 & 0.007 & 0.008 & 0.068 \\
Size & -0.022 & 0.526 & -0.006 & 0.006 \\
MTB & 0.899 & 0.003 & 0.011 & 0.429 \\
Sector f.e. & Yes & & Yes & \\
Year f.e. & Yes & & Yes & \\
N & 2406 & & $3.7 \%$ & \\
Adj R-squared & $2.8 \%$ & & 300 \\
\hline
\end{tabular}

This panel reports coefficient estimates and the statistical significance of these coefficients from OLS models where the dependent variable is the difference between actual earnings and the mean estimate over the standard deviation of the estimates (SUE) or the difference between actual earnings and the mean estimate over the mean estimate (\%FE). "High Sustainability" is an indicator variable that takes the value of one if a firm is included in the High Sustainability group. "Size" is the natural logarithm of market capitalization at fiscal year-end. "MTB" is stock price over book value of equity per share at fiscal year-end. Standard errors are robust to heteroscedasticity and clustered at the firm level. 


\section{Figure 1}

Evolution of $\$ 1$ invested in the stock market in value-weighted portfolios

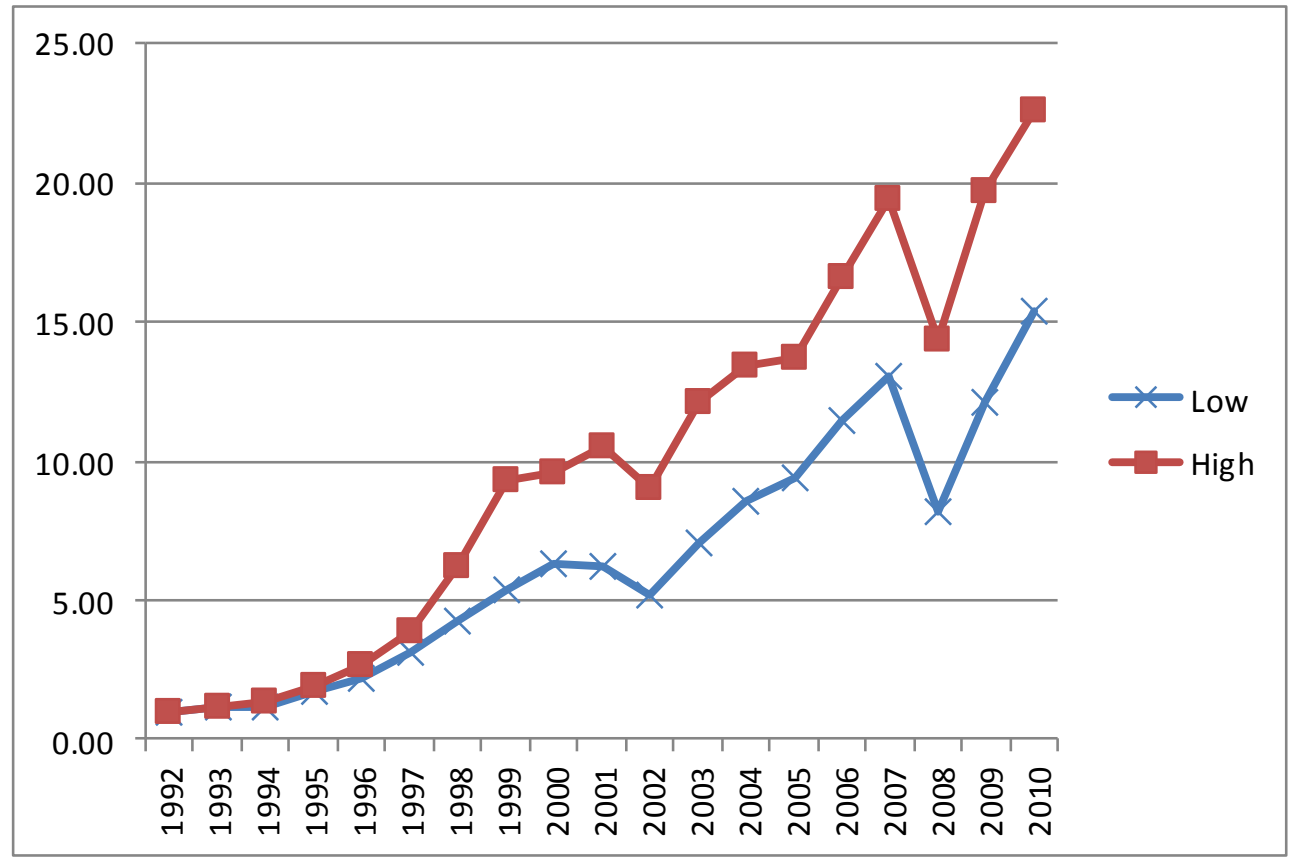

Figure 2

Evolution of $\$ 1$ invested in the stock market in equal-weighted portfolios

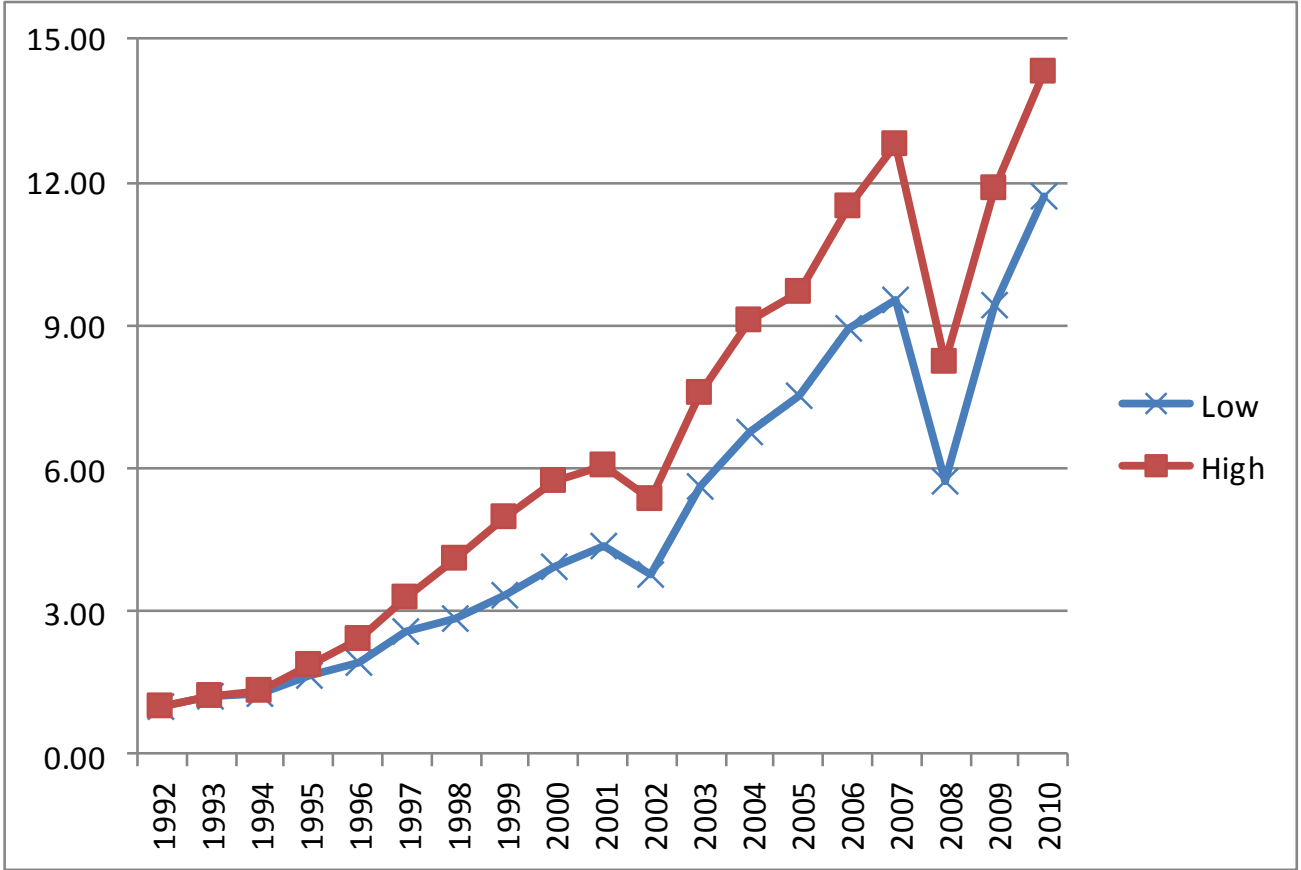




\section{Figure 3}

Evolution of $\$ 1$ of assets based on Return-on-Assets

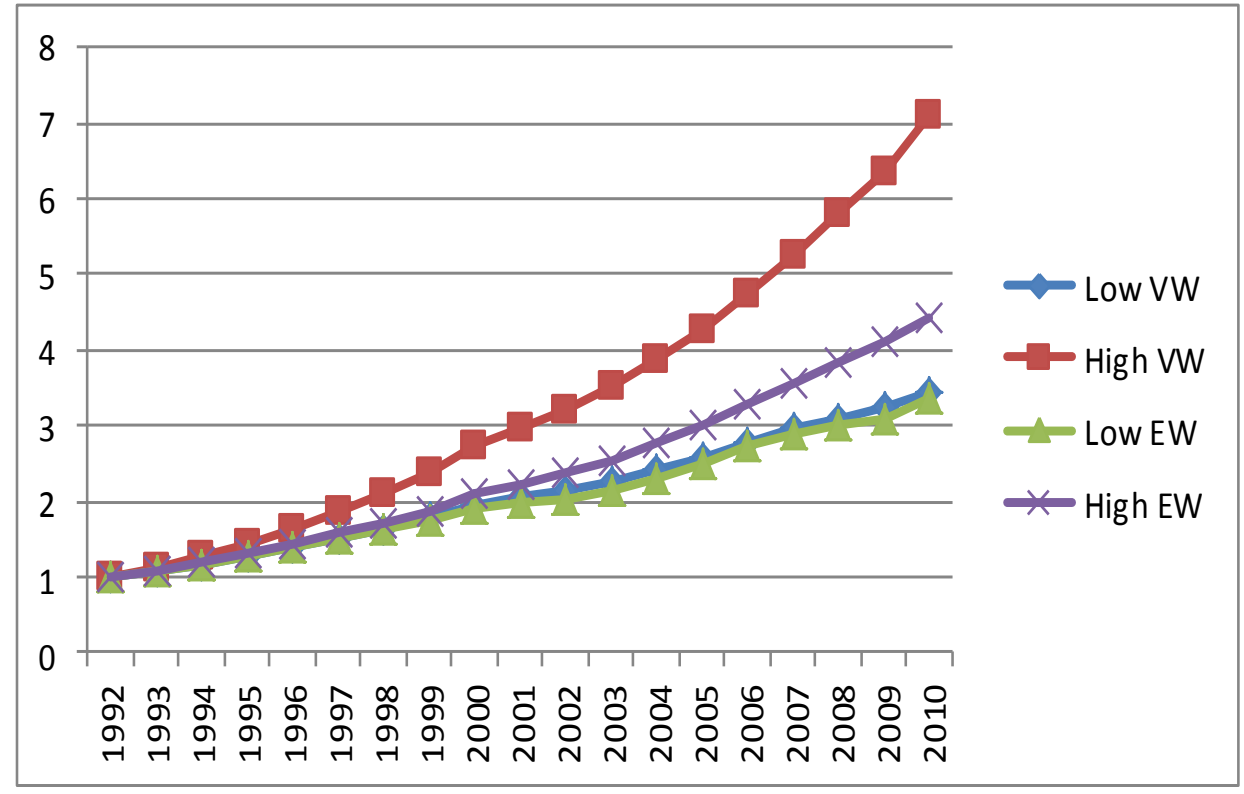

Figure 4

Evolution of $\$ 1$ of equity based on Return-on-Equity

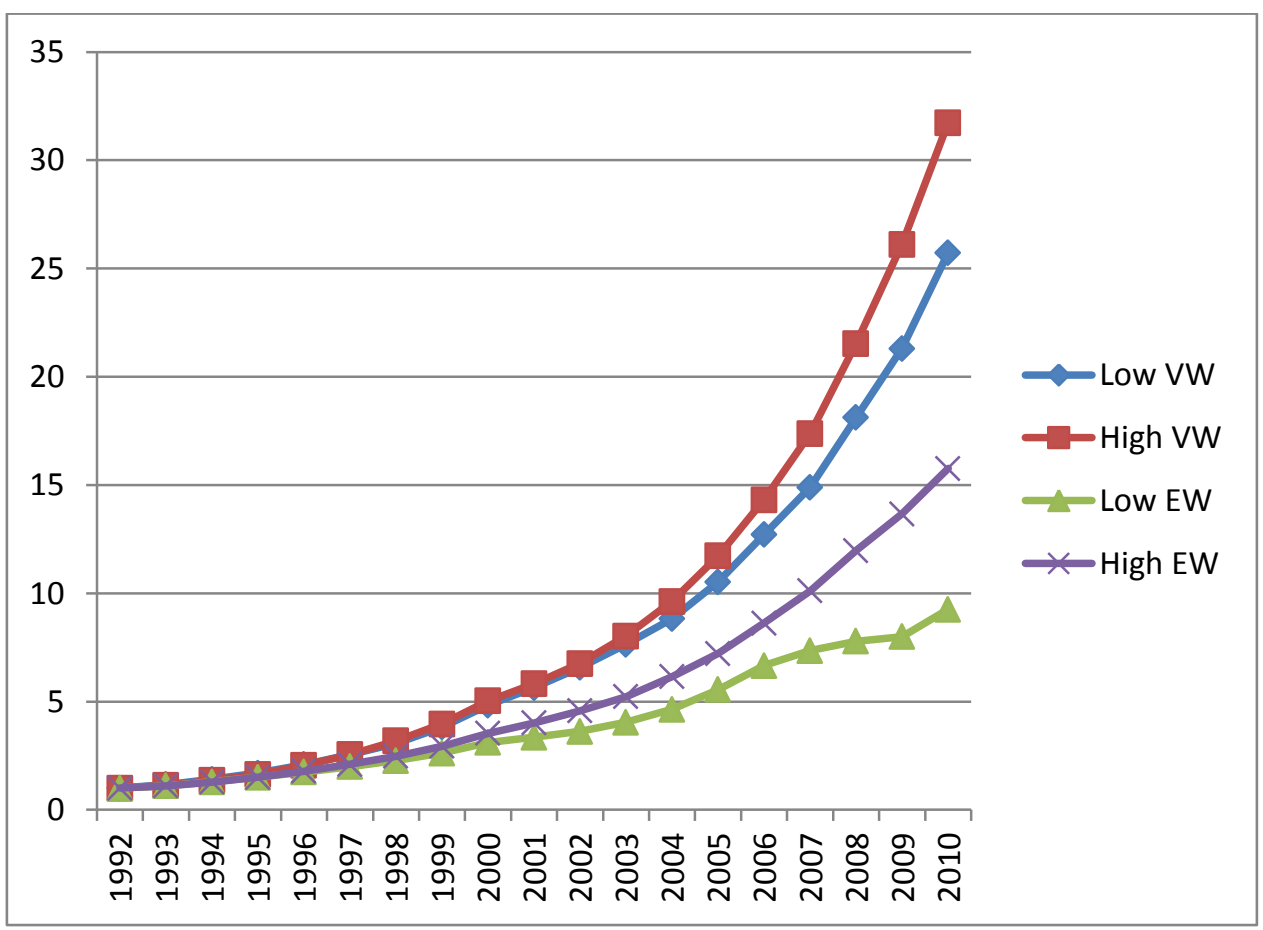




\section{Appendix}

\begin{tabular}{|c|c|}
\hline Name & Description \\
\hline Bonus Plan for Employees/Employees & Does the company provide a bonus plan to most employees? \\
\hline Community/Policy I & Does the company have a policy to strive to be a good corporate citizen or endorse the Global Sullivan Principles? \\
\hline Community/Policy II & Does the company have a policy to respect business ethics or has the company signed the UN Global Compact or follow the OECD guidelines? \\
\hline Diversity and Opportunity/Policy & Does the company have a diversity and equal opportunity policy? \\
\hline Emission Reduction Policy Elements/Emissions & Does the company have a policy to reduce emissions? \\
\hline Emission Reduction/CO2 Reduction & Does the company shows an initiative to reduce, reuse, recycle, substitute, phased out or compensate $\mathrm{CO} 2$ equivalents in the production process? \\
\hline Emission Reduction/Transportation Impact Reduction & Does the company have initiatives to reduce the environmental impact of transportation of its products or its staff? \\
\hline Employee welfare & Does the company have a work-life balance policy? \\
\hline Employment Quality/Policy I & Does the company have a competitive employee benefits policy or ensuring good employee relations within its supply chain? \\
\hline Employment Quality/Policy II & Does the company have a policy for maintaining long term employment growth and stability? \\
\hline Environmental Supply Chain Management & Does the company use environmental criteria (ISO 14000, energy consumption, etc.) in the selection process of its suppliers or sourcing partners? \\
\hline Generous Fringe Benefits & Does the company claim to provide its employees with a pension fund, health care or other insurances? \\
\hline Health \& Safety /Policy & Does the company have a policy to improve employee health \& safety within the company and its supply chain? \\
\hline Human Rights Contractor & Does the company show to use human rights criteria in the selection or monitoring process of its suppliers or sourcing partners? \\
\hline Human Rights/Policy I & Does the company have a policy to guarantee the freedom of association universally applied independent of local laws? \\
\hline Human Rights/Policy II & Does the company have a policy for the exclusion of child, forced or compulsory labor? \\
\hline Internal Promotion & Does the company claim to favor promotion from within? \\
\hline Management Training & Does the company claim to provide regular staff and business management training for its managers? \\
\hline Positive Discrimination & Does the company promote positive discrimination? \\
\hline Product Impact Minimization & Does the company design product features and applications/services that promote responsible, efficient, cost-effective and environmentally preferable use? \\
\hline Product Innovation & Does the company have take-back procedures and recycling programs to reduce the potential risks of products entering the environment? \\
\hline Product Responsibility/Policy I & Does the company have a policy to protect customer health \& safety? \\
\hline Product Responsibility/Policy II & Does the company have a products and services quality policy? \\
\hline Resource Efficiency/Energy Efficiency Policy & Does the company have a policy to improve its energy efficiency? \\
\hline Resource Efficiency/Water Efficiency Policy & Does the company have a policy to improve its water efficiency? \\
\hline Training and Development/Policy & Does the company have a policy to support the skills training or career development of its employees? \\
\hline Waste Reduction Total & Does the company have initiatives to recycle, reduce, reuse, substitute, treat or phase out total waste? \\
\hline
\end{tabular}

This Appendix includes all environmental and social policies that are used to construct the Sustainability Policies index. 